Chapman University

Chapman University Digital Commons

Pharmacy Faculty Articles and Research

School of Pharmacy

3-11-2016

\title{
Design, Synthesis, and Evaluation of Chitosan Conjugated GGRGDSK Peptides as a Cancer Cell- Targeting Molecular Transporter
}

Naglaa Salem El-Sayed

Chapman University

Amir Nasrolahi Shirazi

ChapmanUniversity, shirazi@chapman.edu

Magda Goda El-Meligy

National Research Center, Egypt

Ahmed Kamel El-Ziaty

Ain Shams University

Zenat A. Nagieb

National Research Center, Egypt

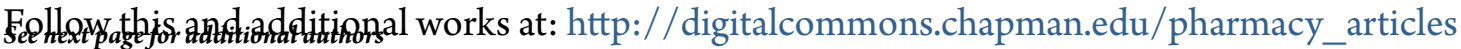

Part of the Amino Acids, Peptides, and Proteins Commons, Biological Phenomena, Cell

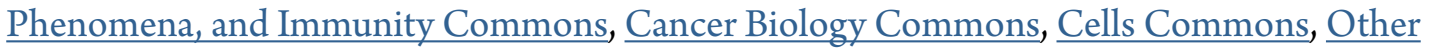
Pharmacy and Pharmaceutical Sciences Commons, and the Pharmaceutics and Drug Design Commons

\section{Recommended Citation}

Naglaa S.El-Sayed, Amir N.Shirazi, Magda G.El-Meligy, Ahmed K.El-Ziaty, Zenat A.Nagieb, Keykavous Parang, Rakesh K.Tiwari, Design, synthesis, and evaluation of chitosan conjugated GGRGDSK peptides as a cancer celltargeting molecular transporter, Int J Biol Macromol. 2016;87:611-622. doi: 10.1016/j.ijbiomac.2016.03.020 


\section{Design, Synthesis, and Evaluation of Chitosan Conjugated GGRGDSK Peptides as a Cancer Cell-Targeting Molecular Transporter}

\section{Comments}

NOTICE: this is the author's version of a work that was accepted for publication in International Journal of Biological Macromolecules. Changes resulting from the publishing process, such as peer review, editing, corrections, structural formatting, and other quality control mechanisms may not be reflected in this document. Changes may have been made to this work since it was submitted for publication. A definitive version was published in International Journal of Biological Macromolecules, volume 87, in 2016. DOI: 10.1016/ j.ijbiomac.2016.03.020

The Creative Commons license below applies only to this version of the article.

\section{Creative Commons License}

\section{(ब) $\Theta \Theta$}

This work is licensed under a Creative Commons Attribution-Noncommercial-No Derivative Works 4.0 License.

\section{Copyright}

Elsevier

\section{Authors}

Naglaa Salem El-Sayed, Amir Nasrolahi Shirazi, Magda Goda El-Meligy, Ahmed Kamel El-Ziaty, Zenat A. Nagieb, Keykavous Parang, and Rakesh Tiwari 


\section{Accepted Manuscript}

Title: Design, synthesis, and evaluation of chitosan conjugated GGRGDSK peptides as a cancer cell-targeting molecular transporter

Author: Naglaa S. El-Sayed Amir N. Shirazi Magda G. El-Meligy Ahmed K. El-Ziaty Zenat A. Nagieb Keykavous

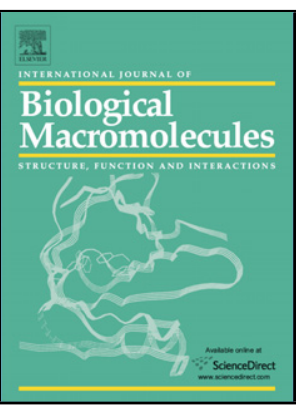
Parang Rakesh K. Tiwari

PII:

DOI:

Reference: S0141-8130(16)30244-6 http://dx.doi.org/doi:10.1016/j.ijbiomac.2016.03.020

To appear in: $\quad$ International Journal of Biological Macromolecules

Received date: $\quad$ 8-2-2016

Revised date: $\quad 1-3-2016$

Accepted date: $\quad$ 9-3-2016

Please cite this article as: Naglaa S.El-Sayed, Amir N.Shirazi, Magda G.El-Meligy, Ahmed K.El-Ziaty, Zenat A.Nagieb, Keykavous Parang, Rakesh K.Tiwari, Design, synthesis, and evaluation of chitosan conjugated GGRGDSK peptides as a cancer celltargeting molecular transporter, International Journal of Biological Macromolecules http://dx.doi.org/10.1016/j.ijbiomac.2016.03.020

This is a PDF file of an unedited manuscript that has been accepted for publication. As a service to our customers we are providing this early version of the manuscript. The manuscript will undergo copyediting, typesetting, and review of the resulting proof before it is published in its final form. Please note that during the production process errors may be discovered which could affect the content, and all legal disclaimers that apply to the journal pertain. 
Design, synthesis, and evaluation of chitosan conjugated GGRGDSK peptides as a cancer cell-targeting molecular transporter

Naglaa S. El-Sayed ${ }^{1,2}$, Amir N. Shirazi², Magda G. El-Meligy ${ }^{1}$, Ahmed K. El-Ziaty ${ }^{3}$, Zenat A. Nagieb $^{1 *}$, Keykavous Parang ${ }^{2 *}$, and Rakesh K.Tiwari ${ }^{2 *}$

${ }^{1}$ Cellulose and Paper Department, National Research Center, Dokki 12622, Cairo, Egypt

${ }^{2}$ Department of Biomedical and Pharmaceutical Sciences, Chapman University School of Pharmacy, Harry and Diane Rinker Health Science Campus, Irvine, California 92618, United States

${ }^{3}$ Chemistry Department, Faculty of Science, Ain Shams University, Abbassia, Cairo, 11566, Egypt

Corresponding author: $\quad$ Prof. Rakesh K Tiwari

E-mail: tiwari@chapman.edu 


\begin{abstract}
Targeting cancer cells using integrin receptor is one of the promising targeting strategies in drug delivery. In this study, we conjugated an integrin-binding ligand (GGRGDSK) peptide to chitosan oligosaccharide (COS) using (sulfo-SMCC) bifunctional linker affording COS-SMCC-GGRGDSK. The conjugated polymer was characterized by FT-IR, ${ }^{1} \mathrm{H}-\mathrm{NMR},{ }^{13} \mathrm{C}-\mathrm{NMR}$, and SEM. COS-SMCCGGRGDSK did not show cytotoxicity up to a concentration of $1 \mathrm{mg} / \mathrm{mL}$ in the human leukemia cell line (CCRF-CEM). The conjugate was evaluated for its ability to enhance the cellular uptake of cellimpermeable cargoes (e.g., FAM and F'-G(pY)EEI phosphopeptide) in CCRF-CEM, and human ovarian carcinoma (SK-OV-3) cancer cell lines. Additionally, RGD modified and unmodified COS polymers were used to prepare nanoparticles by ionic gelation and showed particle size ranging from 187 to $338 \mathrm{~mm}$, and zeta potential of 12.2-18.3 mV using dynamic light scattering. The efficiency of COS-NPs and COS-SMCC-RGDSK NPs was assayed for translocation of two synthetic cytotoxic agents ((2-(2-aminoethylamino)-4-(4-chlorophenyl)-6-(1H-indol-3-yl) nicotinonitrile (ACIN), and 2(2-aminoethylamino)-6-(1H-indol-3-yl)-4-(4-methoxyphenyl)-nicotinonitrile (AMIN)) into CCRFCEM and human prostate (DU-145) cancer cell lines. The results showed a dramatic reduction in the cell viability on their treatment with RGD targeted COS NPs in comparison to paclitaxel (PTX), free drug, and drug-loaded COS NPs.
\end{abstract}

Keywords: Chitosan oligosaccharide, GGRGDSK peptide, Sulfo-SMCC linker, phosphopeptide, ionic gelation, cancer cell lines.

\title{
1. Introduction
}

Over the past three decades, significant efforts have been devoted to develop efficient, nontoxic, drug delivery systems (DDSs) that offer selective translocation and controlled release of the cell impermeable molecular cargoes, such as drugs, proteins, antibodies, genes, and dyes, into the cell cytoplasm to perform their biological activity inside the targeted tissue. Cell-penetrating peptides (CPPs), nanoparticles, and polysaccharides including hyaluronic acid, dextran, water soluble cellulose derivatives, and chitosan derivatives have been used as tools for developing drug delivery systems [1-5].

Chitosan is a cationic polysaccharide composed of randomly distributed $\beta-(1-4)$-linked Dglucosamine and $\mathrm{N}$-acetylated-D-glucosamine units. Chitosan and its derivatives are attractive 
biopolymers due to their biodegradability, low immunogenicity, and biocompatibility, which give them their favorable physicochemical and pharmacokinetic properties [6]. The primary amino groups $\left(\mathrm{NH}_{2}\right)$ on the C-2 position of chitosan D-glucosamine building block creates the positive charge on the chitosan surface that facilitates the intracellular translocation of its payload into the cells [7]. The ability of chitosan to pass through the cell membranes is due to the interaction of its protonated amino groups with the cell membrane phospholipids, which results in a reversible structural change and the opening of tide junction [8]. Moreover, the cationic nature of chitosan and its derivatives has inspired the investigators to use them as promising non-viral gene vectors because of their less cytotoxicity, immunogenicity and mutagenesis response in comparison with the viral vectors and polyarginine or polyethylene imine (PEI) and their ability in the formation of a stable complex with DNA and siRNA [9-12].

Since the utilization of chitosan is hindered by its poor solubility, chemical modification of chitosan is required to modulate its physicochemical and pharmacological properties [13]. These new derivatives increase the stability of the drug or gene/carrier complex, and the polymer ability in protecting its cargo from in vivo serum lytic enzymes, and lysosomal digestion inside the cells [14]. Since the tumor microenvironment such as $\mathrm{pH}$, degree of vasculature, hypoxia, metabolites, receptors upregulation, has been utilized to achieve targeting for diagnosis, or treatment purpose [15-17]. Therefore, attaching a tumor targeting moiety to chitosan [18] such as folic acid [19], galactose [20], or homing peptides $[21,23]$ acted to direct the carrier system selectively to the site of action (organ or tissue). Tumors originated from epithelial cells overexpress heterodimeric glycoproteins consisting of $\alpha$ and $\beta$ subunits, which combine to form various types of integrin receptors found in the extracellular matrix. These receptor proteins have high binding affinity for the ligands containing RGD peptide motifs [24-26]. RGD-based chitosan delivery systems have been widely used in bone tissue engineering and articular cartilage regeneration by enhancing the cell adhesion, growth, and differentiation. However, the use of integrin-targeting chitosan system as drugs and gene delivery to different tumor tissues is limited and still needs further exploration [27-30].

Herein, we report the synthesis of GGRDSK motif as integrin targeting RGD peptide and its immobilization on the surface of water-soluble chitosan oligosaccharide (COS) via a facile strategy using (sulfo-SMCC) cross-linking spacer. The efficiency of chitosan-RGD as a molecular transporter and the cellular uptake mechanistic study were evaluated on a panel of endothelial cancer cell lines 
including; leukemia (CCRF-CEM), ovarian (SK-OV-3), and prostate (DU-145) cancer cell lines as preliminary in vitro study models.

\section{Materials and methods}

\subsection{Materials}

All required organic solvents were purchased from Wilkem Scientific (Pawtucket, RI, USA). Coupling reagents, Rink amide MBHA resin, and Fmoc-amino acid building blocks were purchased from Chem-Impex International Inc. (Wood Dale, IL, USA). Chitosan oligosaccharide and other reagents and chemicals were purchased from Sigma-Aldrich Chemical Co. (Milwaukee, WI, USA).

\subsection{Synthesis of linear peptide $\mathrm{HS}-\left(\mathrm{CH}_{2}\right)_{2} \mathrm{CONH}-\mathrm{GGRGDSK}-\mathrm{CONH} 2$}

In general, the peptide was synthesized by the solid-phase synthesis strategy employing $N-(9-$ fluorenyl)methoxycarbonyl (Fmoc)-based chemistry and Fmoc-L-amino acid building blocks. The sequence of the linear peptide of the sequence (thiopropionyl-GGRGDSK) was synthesized using Tribute automated peptide synthesizer (Protein Technology, Inc., Arizona). 2-(1H-benzotriazole-1yl)-1,1,3,3-tetramethyluronium hexafluoro-phosphate (HBTU) and $0.4 \mathrm{M} \mathrm{N}$-methyl morpholine (NMM) in $N, N$-dimethylformamide (DMF) were used as coupling and activating reagents, respectively. Fmoc deprotection at each step was carried out using piperidine in DMF $(20 \% \mathrm{v} / \mathrm{v})$. The linear peptide carrying protected side chains was assembled on the Rink amide MBHA resin (loading $0.52 \mathrm{mmol} / \mathrm{g}$ ) in $0.40 \mathrm{mmol}$ scale. Then, the resin was washed with DMF (2 times, $10 \mathrm{~min}$ each) and DCM (3 times, 10 min each). After the peptide synthesis was completed the resin was washed with DMF (3 times, $10 \mathrm{~min}$ each) and dichloromethane (DCM, 3 times, $10 \mathrm{~min}$ each). The peptide was cleaved from the resin, and the side chain protecting groups were removed using the final cleavage cocktail $(20 \mathrm{~mL})$; reagent " $\mathrm{R}$ " containing (TFA/ thioanisole/ EDT/ anisole (90:5:3:2 v/v/v/v) by shaking the mixture at room temperature for $6 \mathrm{~h}$. The crude peptide was precipitated by adding cold diethyl ether $\left(\mathrm{Et}_{2} \mathrm{O}, 50 \mathrm{~mL} \times 2\right.$ times $)$ and centrifuged for 10 minutes, then the precipitate was collected, dissolved in a mixture of water/ acetonitrile, and purified by reversed-phase Hitachi HPLC (L-2455) equipped with a Waters XBridge ${ }^{\mathrm{TM}}$ BEH130 Prep C18 column with $\mathrm{OBD}^{\mathrm{TM}} 10 \mu \mathrm{m}(19 \mathrm{~mm}$ x $250 \mathrm{~mm}$ ) reversed-phase column. The purified peptide was lyophilized into powder for assay. High- 
resolution matrix-assisted laser desorption-ionization time-of-flight (MALDI-TOF/TOF) mass spectrometer (ABX SCIEX TOF/TOF) was used to confirm the structure of the final peptide. MALDITOF (m/z) for $\mathrm{C}_{28} \mathrm{H}_{50} \mathrm{~N}_{12} \mathrm{O}_{11} \mathrm{~S}$ Calcd., 762. 3443; found $763.1235[\mathrm{M}+\mathrm{H}]^{+}$.

\subsection{Synthesis of fluorescence-labeled GGRGDSK peptide (GGRGDSK(F'))}

The synthesized GGRGDSK peptide $(38.1 \mathrm{mg}, 0.050 \mathrm{mmole})$ was dissolved in $(1 \mathrm{~mL})$ of anhydrous DMF and $N, N$-diisopropylethylamine (DIPEA, 6 equiv, $52.0 \mu \mathrm{L}$ ). 5(6)-Carboxyfluorescein $N$-hydroxy succinimide ester ( $35.5 \mathrm{mg}, 0.075$ mmole, 1.5 equiv) was dissolved in DMF $(1 \mathrm{~mL})$ and added dropwise to the solution of the peptide under stirring at room temperature in the dark for $24 \mathrm{~h}$. Diethyl ether ( $\mathrm{Et}_{2} \mathrm{O}, 25 \mathrm{~mL}$ x 2 times) was added for precipitation; then the mixture was centrifuged for $10 \mathrm{~min}$. The precipitate was collected, dissolved, and purified by HPLC (L-2455) equipped with a reversed-phase column as described above to yield GGRGDSK $\left(\mathrm{F}^{\prime}\right)\left(\mathrm{F}^{\prime}=\right.$ Fluorescein) that underwent lyophilization. The structure of the final compound was confirmed by MALDI-TOF/TOF mass spectrometry. MALDI-TOF (m/z) [C $\left.\mathrm{C}_{49} \mathrm{H}_{60} \mathrm{~N}_{12} \mathrm{O}_{17} \mathrm{~S}\right]$ : Calcd, $1120.3920 ;$ Found, $1121.4078[\mathrm{M}+\mathrm{H}]^{+}$.

\subsection{Synthesis of COS-SMCC}

Chitosan $(\mathrm{COS}, 1 \mathrm{~g}, \mathrm{MWt}=4000-5000 \mathrm{Da}$, polydispersity $(\mathrm{Mw} / \mathrm{Mn}) 1.25$, with a degree of deacetylation $=90 \%$ ) was dissolved completely in $100 \mathrm{~mL}$ of phosphate buffer solution (PBS), and the $\mathrm{pH}$ was adjusted to 7.5 Then, a solution of sulfosuccinimidyl 4-(Nmaleimidomethyl)cyclohexane-1-carboxylate (sulfo-SMCC, $43.6 \mathrm{mg}, 0.1 \mathrm{mmol}$ in $10 \mathrm{~mL}$ of PBS) was added dropwise under stirring at room temperature with magnetic stirring for $24 \mathrm{~h}$. The resulted COS-SMCC was purified using dialysis tube (MWCO $1000 \mathrm{Da}$ ) against distilled water for 3 days to remove the unreacted (Sulfo-SMCC) and any byproducts with continuous changing the milliQ-water 3 times/day and then freeze-dried affording product as a powder.

\subsection{Conjugation of GGRGDSK to COS-SMCC}

The COS-SMCC polymer $(100 \mathrm{mg})$ was dissolved in $(10 \mathrm{~mL})$ of phosphate buffered solution at $\mathrm{pH} 6.5$ and stirred for $30 \mathrm{~min}$. Then, the linear peptide GGRGDSK (15.2 $\mathrm{mg}, 0.020 \mathrm{mmol})$ or GGRGDSK(F') (22.4 mg, $0.020 \mathrm{mmol})$ was dissolved in buffer solution and added dropwise to COSSMCC polymer solution over $30 \mathrm{~min}$. Then the reaction was continued under stirring at room 
temperature in dark for additional $48 \mathrm{~h}$. The resulting CS-SMCC-peptide conjugates were purified using a dialysis membrane (MWCO $1000 \mathrm{Da}$ ) for three days against milliQ-water (3 times/ day). Then, the solution of each copolymer conjugate was freeze-dried to obtain the powder of COSSMCC-GGRGDSK or COS-SMCC-GGRGDSK(F').

\section{6. FT-IR}

FT-IR spectra for COS, COS-SMCC, and COS-SMCC-GGRGDSK were obtained with (Alpha FT-IR Spectrometer/Platinum ATR from Bruker as described in results and discussion section.

\section{7. ${ }^{1} \mathrm{H}-\mathrm{NMR} \&{ }^{13} \mathrm{C}-\mathrm{NMR}$}

${ }^{1} \mathrm{H}$ NMR and ${ }^{13} \mathrm{C}$ NMR spectra of the polymers were recorded on a Bruker Avance III HDTM 400 NMR spectrometer in $\mathrm{D}_{2} \mathrm{O}$. Chemical shifts are shown in parts per million (ppm) as described in results and discussion section.

\subsection{SEM}

The samples of COS, COS-SMCC and COS-SMCC-GGRGDSK were sprinkled onto an aluminum stub that was covered with copper tape. Samples were imaged with a SEM Phillips XL-30 scanning electron microscope (SEM).

\subsection{Preparation of nanoparticles and drug loading}

The formulation of chitosan nanoparticles was achieved according to the previously reported method [31] with some modifications. In general, COS (3 mg) or COS-SMCC-GGRGDSK (3 mg) were dissolved in $(1 \mathrm{~mL})$ of Millipore double distilled water, and the $\mathrm{pH}$ was then adjusted to 5.4 by adding a few drops of acetic acid to the solution then the nanoparticles formed spontaneously upon addition of $(1 \mathrm{~mL})$ of an aqueous solution of sodium tripolyphosphate (TPP, 1, 1.5, and $2 \mathrm{mg} / \mathrm{mL}$ ) and magnetic stirring for $15 \mathrm{~min}$ at room temperature. For loading of 2-(2-aminoethylamino)-4-(4chlorophenyl)-6-(1H-indol-3-yl) nicotinonitrile (ACIN), and 2-(2-aminoethylamino)-6-(1H-indol-3yl)-4-(4-methoxyphenyl)-nicotinonitrile (AMIN), cytotoxic agents $(0.19 \mathrm{mg}, 0.5 \mathrm{mmol})$, they were dissolved in $1 \mathrm{~mL}$ of $10 \%$ DMSO in water and mixed with the polymer solution by magnetic stirring until a homogenous clear solution was observed. Then, TPP solution $(1.5 \mathrm{mg} / 1 \mathrm{~mL}$ in double distilled $\mathrm{H}_{2} \mathrm{O}$ ) was added dropwise to the polymer/drug solution where the solution turned to be 
turbid due to the aggregation of the molecules into nanoparticles (NPs). The NPs were collected and purified by centrifugation at $4500 \mathrm{rpm}$ for $30 \mathrm{~min}$. Supernatants which contains the unloaded drug were collected and freeze dried.

\subsection{Loading efficiency of drug loaded NPs}

The loading efficiency (LE) was determined by weighing the amount of unloaded drug recovered from lyophilization of the supernatant, obtained after centrifugation of NPs. The drug loading efficiency was calculated according to the following equation:

Loading efficiency $(\%)=\left(\mathrm{W}_{\text {initial }} / \mathrm{W}_{\text {free }}\right) / \mathrm{W}_{\text {initial }} * 100 \%$.

Where, $\mathrm{W}_{\text {initial, }}$ and $\mathrm{W}_{\text {free }}$ are the initial weight of the drug(total amount), and the weight of free drug determined in the supernatant after centrifugation and lyophilization respectively (unloaded). Each sample was determined in duplicate.

\subsection{Determination of particles size and zeta potential}

The pellets were resuspended in phosphate buffered saline. The size and zeta potential of blank NPs and drug-loaded NPs were measured by dynamic light scattering (DLS) using Zetasizer (3000HS; Malvern Instruments Ltd, Worcestershire, UK).

\subsection{Cell culture}

Human leukemia cell line (CCRF-CEM, ATCC no. CCL-119), human ovarian carcinoma (SK-OV-3, ATCC no. HTB- 77), and human prostate cancer cell line (DU-145, ATCC no. HTB-81) were obtained from American Type Culture Collection. CCRF-CEM cells were grown on $75 \mathrm{~cm}^{2}$ cell culture flasks with Roswell Park Memorial Institute (RPMI)-16 medium. Eagle's minimum essential medium (EMEM) was used for SK-OV-3 and DU-145 cells, supplemented with $10 \%$ fetal bovine serum (FBS), and 1\% penicillin-streptomycin solution (10,000 units of penicillin and $10 \mathrm{mg}$ of streptomycin in $0.9 \% \mathrm{NaCl}$ ) in a humidified atmosphere of $5 \% \mathrm{CO}_{2}, 95 \%$ air at $37{ }^{\circ} \mathrm{C}$. All bioassays were performed in triplicate.

\subsection{Cytotoxicity of COS-SMCC-GGRGDSK}

CCRF-CEM $(30,000)$ cells were seeded in $0.1 \mathrm{~mL}$ per well in 96 -well plates for $24 \mathrm{~h}$ at $37{ }^{\circ} \mathrm{C}$ before the experiment. The cells were treated with different concentrations $(0.5,1.0$, and $2.0 \mathrm{mg} / \mathrm{mL})$ 
of COS-SMCC-GGRGDSK, in serum-containing medium and incubated for $24 \mathrm{~h}$ at $37{ }^{\circ} \mathrm{C}$ in a humidified atmosphere of $5 \% \mathrm{CO}_{2}$. Cell viability was then determined by measuring the fluorescence intensity at $490 \mathrm{~nm}$ using a SpectraMax M2 microplate spectrophotometer. The percentage of cell survival was calculated as [(OD value of cells treated with the tested polymer) - (OD value of culture medium $)] /[(\mathrm{OD}$ value of control cells $)-(\mathrm{OD}$ value of culture medium $)] \times 100 \%$.

2.14. Cellular uptake study of COS-SMCC-GGRGDSK(F') (COS-SMCC conjugated to the GGRGDSK(F’) peptide)

CCRF-CEM and SK-OV-3 cells were grown on coverslips in 6-well plates with complete EMEM media for overnight prior to the experiment. Then the medium was removed and washed with opti-MEM. A stock solution of COS-SMCC-GGRGDSK( $\left.\mathrm{F}^{\prime}\right)\left(1 \mathrm{mg} / \mathrm{mL}\right.$ in $\left.\mathrm{H}_{2} \mathrm{O}\right)$ was added to the wells. After $3 \mathrm{~h}$ incubation at $37{ }^{\circ} \mathrm{C}$, the media were removed. The cells were digested with $0.25 \%$ trypsin/0.53 mM EDTA for $5 \mathrm{~min}$ to detach from the plate. The cells were collected and centrifuged at $2500 \mathrm{rpm}$ for $5 \mathrm{~min}$. Then, they were washed with PBS (without calcium and magnesium) twice. Finally, the cells were re-suspended in flow cytometry buffer and analyzed by flow cytometry (BD FACS Calibur) using FITC channel, and CellQuest software. The data presented are based on the mean fluorescence signal for 10,000 cells collected. All assays were carried out in triplicate, and 5(6)carboxyfluorescein (FAM) at $(5 \mu \mathrm{M})$ was used as a negative control.

\subsection{Cellular uptake of fluorescein labeled phosphopeptide F'-G(pY)EEI}

The cellular uptake assays were performed via fluorescence activated cell sorting (FACS) analysis in CCRF-CEM. F'-G(pY)EEI was added to the well plates in a $5 \mu \mathrm{M}$ concentration, and COS-SMCCGGRGDSK, were added to the well plates at a concentration of $1.0 \mathrm{mg} / \mathrm{mL}$. The cells were incubated at $37{ }^{\circ} \mathrm{C}$ with $5 \%$ carbon dioxide for $3 \mathrm{~h} .0 .25 \%$ of trypsin-EDTA $(0.53 \mathrm{mM})$ was then added to the well plates to detach the cells. $2 \mathrm{~mL}$ of the complete media was then added to deactivate the trypsin. The cells were centrifuged at $2500 \mathrm{rpm}$ for $5 \mathrm{~min}$, and the supernatant was removed. The cells were washed with PBS twice, and $400 \mu \mathrm{L}$ of FACS buffer was added to the cells. The cells were resuspended in the FACS, and the cells were analyzed via flow cytometry.

2.16. Cellular uptake studies of COS-SMCC-GGRGDSK $\left(F^{\prime}\right)$ in the presence of inhibitors

CCRF-CEM and SK-OV-3 cell lines were seeded in 6-well plates $\left(1 \times 10^{7}\right.$ cells/well $)$ in serum-free RPMI medium. 6-Well plates were used to seed the cells to perform the mechanistic investigations. 
Multiple endocytic inhibitors, such as chlorpromazine $(30 \mu \mathrm{M})$, methyl- $\beta$-cyclodextrin $(2.5 \mathrm{mM})$, and chloroquine $(100 \mu \mathrm{M})$, were incubated with the cells for $40 \mathrm{~min}$ before the incubation with COSSMCC-GGRGDSK $\left(F^{\prime}\right)$. Then, the fluorescein-labeled polymer was added to the wells containing cells, and the concentrations of inhibitors were maintained during the incubation time $3 \mathrm{~h}$ at $37^{\circ} \mathrm{C}$. To induce ATP depletion, the cells were preicubated with $0.5 \%$ of $150 \mathrm{mM}$ sodium azide in opti-MEM prior to the addition of the copolymer followed by $3 \mathrm{~h}$ incubation. Similar FACS protocol was performed to measure the uptake of the polymer.

\subsection{Antiproliferative assay of ACIN and AMIN cytotoxic agents loaded nanoparticles}

The antiproliferative assay of ACIN, AMIN, and ACIN, AMIN loaded with COS, and COSSMCC-GGRGDSK NPs were performed via MTS proliferation assay in CCRF-CEM and DU-145

cell lines and tested in triplicate. The results were compared with that of free PTX (paclitaxel) by MTS assay using CellTiter 96 AQueous One Solution Cell Proliferation Assay Kit (Promega of USA). All cells were plated overnight in 96 well plates with a density of 5,000 cells per well in 100 $\mu \mathrm{L}$ appropriate growth media overnight in a 96 well plate. The cytotoxic drugs (PTX, ACIN, AMIN), ACIN/COS NPs, AMIN /COS NPs, ACIN/COS-SMCCGGRGDSK NPs, and AMIN/COSSMCC-GGRGDSK NPs were added to the wells at drug concentration equivalent to $30 \mu \mathrm{M}$ for the free drug or the drug-loaded NPs. The cells were incubated at $37{ }^{\circ} \mathrm{C}$ with $5 \%$ carbon dioxide for $96 \mathrm{~h}$. Then $20 \mu \mathrm{L}$ of MTS reagent was added to each of the 96 well plates. The CCRF-CEM cells were incubated for $3 \mathrm{~h}$, and DU-145 cells were incubated for $1 \mathrm{~h}$ at $37{ }^{\circ} \mathrm{C}$ with $5 \%$ carbon dioxide. The absorbance of the formazan product was measured at $490 \mathrm{~nm}$ using microplate reader. The percentage of cytotoxicity was calculated as [(OD value of cells treated with the tested compound) - (OD value of culture medium) $] /[(\mathrm{OD}$ value of control cells $)-(\mathrm{OD}$ value of culture medium $)] \times 100 \%$.

\section{Results and Discussion}

3.1. Synthesis of $\mathrm{HS}-\left(\mathrm{CH}_{2}\right)_{2} \mathrm{CONH}-\mathrm{GGRGDSK}-\mathrm{CONH}_{2}$ and fluorescein-labeled GGRGDSK(F') peptides.

The peptide sequence (HS- $\left.\left(\mathrm{CH}_{2}\right)_{2} \mathrm{CONH}-\mathrm{GGRGDSK}-\mathrm{CONH}_{2}\right)$ was assembled on rink amide resin according to the Fmoc/tBu solid phase peptide chemistry, following our protocol of peptide synthesis described by Mandal et al. [1]. HBTU, and 0.4 M NMM were used as coupling, and activating agents for the amino acids coupling in the peptide synthesis, followed by cleavage from 
resin to afford crude product which was purified by using preparative reversed-phase HPLC. The structures of the compounds was confirmed by high-resolution MALDI-TOF/TOF MS, which showed the peak at $762 \mathrm{Da}$, corresponding to $[\mathrm{M}+\mathrm{H}]^{+}$. The peptide sequence was designed to have a lysine moiety at the $C$-terminal to provide a free $\mathrm{NH}_{2}$ group at its side chain to be used for the conjugation with 5(6)-carboxyfluorescein $N$-hydroxysuccinimide ester dye (FAM) for studying the cellular uptake of chitosan conjugated RGD peptide. Fluorescence-peptide was prepared in solution phase using DIPEA as a base for coupling, and the completion of the reaction was confirmed by MALDI mass, which showed a typical peak at 1121 Da corresponds to $[\mathrm{M}+\mathrm{H}]^{+}$. Meanwhile, two glycine moieties were added at the $N$-terminal acting as a spacer between the polymer and the integrin recognition sequence (RGD) of the peptide. We have added thiopropoinic acid as a source for the free sulfhydryl group of the peptide chain, allowing its conjugation to the maleimide arm of the crosslinking reagent (Schemes $\mathbf{1}$ and 2).

\subsection{Coupling of chitosan oligosaccharide to sulfo-SMCC linker and GGRGDSK peptide}

The strategy involved first amide bond formation between the primary $\mathrm{NH}_{2}$ group of COS and the reactive succinimidyl-4-( $N$-maleimidomethyl)cyclohexane-1-carboxylate (sulfo-SMCC) crosslinking spacer $(8.3 \AA)$ at $\mathrm{pH} 7.5$ which was followed by coupling with the peptide $\mathrm{HS}-\left(\mathrm{CH}_{2}\right)_{2} \mathrm{CONH}-$ GGRGDSK-CONH 2 or HS- $\left(\mathrm{CH}_{2}\right)_{2} \mathrm{CONH}-\mathrm{GGRGDSK}\left(\mathrm{F}^{\prime}\right)-\mathrm{CONH}_{2}$, through the formation of stable thioether bond (Scheme 3). The water-soluble chitosan oligosaccharide (COS) was modified by immobilization of (GGRGDSK) as an integrin-targeting peptide motif. The copolymers structure and morphology were characterized by FT-IR, ${ }^{1} \mathrm{H}-\mathrm{NMR},{ }^{13} \mathrm{C}-\mathrm{NMR}$, and SEM. To the best of our knowledge, this is the first report for conjugation of RGD peptide to COS using sulfo-SMCC cross linker and evaluation of its efficacy as a molecular transporter by a panel of epithelial cancer cell lines. According to the literature, the RGD peptide motif was immobilized directly without spacer on the chitosan backbone through amide linkage between the carboxylic group of carboxymethyl chitosan and the $N$-terminal amino of the peptide [28], or through the derivatization of chitosan high molecular weight with 2-iminothiolane linker, and subsequent disulfide bridge formation between the peptide and chitosan [29]. 


\subsection{Characterization of the COS-SMCC-GGRGDSK}

\subsubsection{FT-IR}

Fig. 1 depicts the FT-IR for COS, COS-SMCC, and COS-SMCC-GGRGDSK in the FT-IR spectrum of COS the stretching vibrational bands at $1673 \mathrm{~cm}^{-1}$ and $1550 \mathrm{~cm}^{-1}$ correspond to the stretching $\mathrm{C}=\mathrm{O}$ of the secondary amide $\left(\mathrm{NHCOCH}_{3}\right)$ and the bending $\mathrm{N}-\mathrm{H}$ band of the primary $\mathrm{NH}_{2}$, respectively. For COS-SMCC, the stretching vibrational bands at $1668 \mathrm{~cm}^{-1}$ and $1626 \mathrm{~cm}^{-1}$ correspond to the secondary amide groups due to the conjugation between COS and sulfo-SMCC, in addition to the bending vibrational band at $1531 \mathrm{~cm}^{-1}$ for the $\mathrm{N}-\mathrm{H}$.

The two stretching vibrational bands at $1093 \mathrm{~cm}^{-1}$ and $1053 \mathrm{~cm}^{-}{ }^{1}$ were assigned to C-O-C bond. For COS-SMCC-GGRGDSK, the shifting of stretching vibrational bands as they appeared at 1638 $\mathrm{cm}^{-1}$ and $1672 \mathrm{~cm}^{-1}$ for $(\mathrm{C}=\mathrm{O})$ indicate the presence of primary amide groups at the $C$-terminal of the conjugated peptide as well as the contribution of the other secondary amide group on the molecules, and the increased intensity of the bending vibrational band at $1535 \mathrm{~cm}^{-1}$ that was attributed to $\mathrm{H}-\mathrm{N}$ bending is due to the conjugation of the peptide to COS-SMCC and the stretching vibrational band at 1085-1031 cm-1 assigned for C-O-C. [5, 33, 34].

\subsection{2. ${ }^{1} \mathrm{H}-\mathrm{NMR} \&{ }^{13} \mathrm{C}-\mathrm{NMR}$}

The ${ }^{1} \mathrm{H}-\mathrm{NMR}$ and ${ }^{13} \mathrm{C}-\mathrm{NMR}$ of $\mathrm{COS}$ and COS-SMCC and COS-SMCC-GGRGDSK conjugates are shown in Fig. 2a. ${ }^{1} \mathrm{H}-\mathrm{NMR}$ of $\operatorname{COS}\left(\mathrm{D}_{2} \mathrm{O}\right)$ showed $\delta$ values at 1.96, 3.04, 3.25, 3.63 $3.79,4.02$, and $4.48 \mathrm{ppm}$ are attributed to the acetylated and deacetylated glucosamine units in the $\mathrm{COS}$ chain. The ${ }^{13} \mathrm{C}-\mathrm{NMR}$ revealed the existence of these signals $\mathrm{CH}_{3} \mathrm{Ac}$ (22.57 ppm), C-2-C6 (56.4, 60.43, 70.38, 74.8, $76.24 \mathrm{ppm}), \mathrm{C}-1$ (97.89 ppm), and one signal for CO at (182.67 ppm).

In the case of COS-SMCC, its ${ }^{1} \mathrm{H}-\mathrm{NMR}$ revealed the existence of the following signals at $\delta$ values $(1.31,1.35,1.962 .77,2.93,3.10,3.44,3.55,3.66,3.83,4.29,4.25,4.49)$ for CH-2,СН-3, СН4 of anhydroglucoseamine unit and $\mathrm{CH}_{2}$ SMCC linker, and $\mathbf{C H}-1$ of anhydroglucoseamine unit as the protons from SMCC linker overlapped with COS protons in this region. However, the existence of a signal at 6.74 for $(\mathrm{CH}=\mathrm{CH}$ the maleimide $)$, and a signal at $7.84 \mathrm{ppm}$ that could be assigned to the amidic proton resulted from the coupling of COS the linker. Moreover, the appearance of new signals in ${ }^{13} \mathrm{C}$-NMR at $\delta$ values $(19.23,21.82,31.23,37.09,55.50,60.12,62.39,66.44,69.93,72.93,74.49$, 75.94 (for C-2, C-3, C-4, C-5 and C-6 of anhydroglucose amine unit and SMCC linker), and 97.54 (C1 of anhydroglucoseamine unit). The $\delta$ value at 116.00 and $117.44 \mathrm{pm}$ are for $\mathrm{C}=\mathrm{C}$ of the 
maleimide arm. While, the $\delta$ value at $155.76,164,65$, and 178.78 are for amide $\left(3 \mathrm{SP}^{2}, \mathbf{C}=\mathbf{O}\right)$, that confirm the successful conjugation of SMCC linker to COS chain.

Coupling of GGRGDSK peptide motif to COS-SMCC resulted in the disappearance of the maleimide proton at $6.75 \mathrm{ppm}$ in ${ }^{1} \mathrm{H}-\mathrm{NMR}$, and the loss of $\mathrm{C}=\mathrm{C}$ signals at $115.9 \mathrm{ppm}$ in $\mathrm{C}-\mathrm{NMR}$ due to the formation of the thioether bond double bonds, and the appearance of new signals in both ${ }^{1} \mathrm{HNMR}$ and ${ }^{13} \mathrm{C}-\mathrm{NMR}$. For examples, the signal at $\delta 8.38 \mathrm{ppm}$ was due to the contribution of the primary amide proton at the $C$-terminal of the peptide chain. The detection of a signal at $4.35 \mathrm{ppm}$ that was assigned for the $\alpha \mathbf{H}-\mathbf{C}$ along the peptide chain, in addition to the signals at 1.41, 1.59, 1.75, $2.00,2.65,2.70$, and $4.30 \mathrm{ppm}$ due to the contribution of the amino acids side chains, Fig. 2a. The spectra analysis for ${ }^{13} \mathrm{C}$-NMR revealed the presence of different 11 signals at $\delta$ values $(22.41,24.18$, $25.53,27.59,29.65,32.76,34.82,38.26,39.37,40.48,42.86,51.76,54.05,55.1,56.70,59.28,61.27$, $70.75,75.40,76.25 \mathrm{ppm})$ for $\mathrm{sp}^{3}$ carbon atoms, the characteristic signal at $\delta(156.90 \mathrm{ppm})$ for $\mathrm{C}=\mathrm{N}$ of the arginine side chain, and $(170.72,170.96,171.87,173.54,174.13,174.99,175.59,176.52$, and $177.03 \mathrm{ppm}$ that are assigned to 10 different amide carbonyls in COS-SMCC-GGRGDSK system [5, 32, 34], Fig. $2 b$.

\subsubsection{Morphology characterization by scanning electron microscopy SEM}

The effect of the immobilization process on the morphology of COS was also investigated by SEM technique, where the cross-section SEM images of COS (a), COS-SMCC (b), COSGGRGDSK (c), indicated highly interconnected morphological structure. Since the morphology changed from granulated to a fibrous cross-linked polymer having pores between the polymer chains, Fig. 3.

\subsection{Biology}

\subsubsection{Cytotoxicity assay of COS-SMCC-GGRGDSK}

The cytotoxicity of COS-SMCC-GGRGDSK peptides was evaluated in non-adherent human leukemia cell line (CCRF-CEM) at different concentrations $(0.5,1$, and $2 \mathrm{mg} / \mathrm{mL})$ using MTS assay after $24 \mathrm{~h}$ incubation, Fig. 4. COS-SMCC-GGRGDSK did not show significant toxicity at 0.5 and 1.0 $\mathrm{mg} / \mathrm{mL}$. Meanwhile, the cell viability was reduced by $20 \%$ at $2 \mathrm{mg} / \mathrm{mL}$ polymer concentration. Therefore, the copolymer concentration of $1 \mathrm{mg} / \mathrm{mL}$ was used as a safe delivery system in our further studies.

3.4.2. The cellular uptake of FAM hydrophobic dye 
COS-SMCC-GGRGDSK was used to translocate 5(6)-carboxyfluorescein (FAM or F') as a hydrophobic cargo in both SK-OV-3 as adherent cancer cell line, and CCRF-CEM as nonadherent cancer cell line by using the flow cytometry method. The fluorescein-labeled copolymer was compared for its cellular uptake efficiency versus free FAM, which used in this study as a negative control. The results showed that the unconjugated FAM had very limited cellular uptake when it was incubated with both SK-OV-3 and CCRF-CEM cells. While the fluorescence intensity was greatly enhanced by more than 10 folds in case of FAM-labeled copolymer compared to free FAM in both cell lines, as shown in Fig. 5.

\subsubsection{Cellular uptake mechanistic study of COS-SMCC-GGRGDSK(F')}

Endocytosis is one of the major mechanisms of cargoes cellular uptake. Micropinocytosis, phagocytosis, and receptor-mediated endocytosis, which contain clathrin-mediated pathways, are the most known endocytosis pathways [35]. Studying the mechanism of COS-SMCC-GGRGDSK cellular uptake helps to get a better understanding and improving the efficiency of that delivery system.

As it is shown in fig. 6, the cellular uptake by CCRF-CEM and SKOV-3 for COSGGRGDSK $\left(F^{\prime}\right)$ was not inhibited by the endocytic inhibitor methyl- $\beta$-cyclodextrin, which acts to remove cholesterol out of the cell membrane, and interferes with the fluid phase; meaning that micropinocytosis and phagocytosis pathways are not responsible in the endocytosis process. The presence of chloroquine did not affect the polymer cellular uptake in case of CCRF-CEM, but the uptake was enhanced by 1.5 fold in SK-OV-3 cells. Chloroquine reduces the $\mathrm{pH}$ in endosomes. As a result, it blocks the endosomal fusion keeping the molecular cargos inside the endosome. Chlorpromazine reduced the uptake in CCRF cell lines by 2.5 folds while its effect was negligible in SK-OV cells. Chlorpromazine is a cationic endocytic inhibitor that acts by inhibiting the formation of the clathrin-coated pit by the reversible translocation with the cell membrane receptor, therefore, inhibits the clathrin-mediated pathway in CCRF-CEM but not in SK-OV-3[36]. On the other hand, the uptake was proved to be energy dependent in both cell lines since its rate was diminished by the addition of $\mathrm{NaN}_{3}$, which act to block the ATP production by oxidative phosphorylation. Also, the reduction of incubation temperature from $37{ }^{\circ} \mathrm{C}$ to $4{ }^{\circ} \mathrm{C}$ reduced dramatically the copolymer cellular uptake by $50 \%$. These data suggested that the ATP depletion, the decrease in incubation temperature, 
and the type of cell line are the parameters that affect the rate of internalization of for COSGGRGDSK(F').

\subsubsection{Cellular uptake study of fluorescent-labeled phosphopeptide F'-G(pY)EEI}

Phosphopeptides have been used as reagent probes to mimic phosphoproteins involved in signal transduction. They are valuable reagent probes for studying the protein-protein and proteinligand interactions, determination of substrate specificity of phosphatases, and identification of phosphotyrosine binding domains (PTB) [37]. The cellular uptake of phosphopeptides is very limited due to the negatively charged phosphate groups, and their hydrophobic nature. Therefore, several strategies have been employed to promote their transportation into the cell cytoplasm. We investigated the potential application of COS-SMCC-GGRGDSK in translocating the fluoresceinlabeled phosphopeptide namely $\mathrm{F}^{\prime}-\mathrm{G}(\mathrm{pY}) \mathrm{EEI}$, fig. 7a as a representative example of negatively charged cargo. FACS analysis, showed that loading of $F^{\prime}-G(p Y) E E I$ [38], with COS-SMCCGGRGDSK versus $\mathrm{F}^{\prime}-\mathrm{G}(\mathrm{pY}) \mathrm{EEI}$ alone in a physical mixture helped to translocate the phosphopeptide into the cell cytoplasm and improved its cellular uptake by 18 times in CCRF-CEM cells at polymer concentration of $1 \mathrm{mg} / \mathrm{mL}$, and increased the uptake to 24 fold by doubling the concentration, Fig.7b. These data suggest that the electrostatic interactions between the positively charged amino group of chitosan and the negatively charged phosphate group of phosphopeptide are the main driving force for improving the cellular uptake of the phosphopeptide that was dependent on the polymer concentration.

\subsubsection{Preparation and characterization of COS, COS-GGRGDSK NPs, and drug loading}

COS nanoparticles were prepared by ionic gelation method where a solution of TPP was added to the polymer solution under magnetic stirring. The aggregation of the polymer into nanoparticles was due to the ionic electrostatic interactions between the polymer positively charged $\mathrm{NH}_{2}$ groups and the negatively charged phosphate groups of TPP that eventually led to the reduction of aqueous solubility of the polymer. Since the ratio between COS and TPP affects the NPs size and zeta potential. Therefore, the effect of polymer/TPP ratio on the NPs size was studied by fixing the polymer weight ( $3 \mathrm{mg} / \mathrm{mL})$ and changing the weight of TPP $(1,1.5$, and $2 \mathrm{mg} / \mathrm{mL})$ in order to find the optimum ratio that results in NPs with small average size, and proper positive zeta potential (Table 1). The NPs size and the positive value of zeta potential decreased by increasing the polymer/TPP ratio. The ratio of 1:2 resulted in smaller sizes (187.3 and $250.7 \mathrm{~nm})$ but those NPs had 
a lower positive zeta potential (13.2 and $15.9 \mathrm{mV}$ ) compared to the NPs produced by 1:1.5 ratio that had $(209$ and $301 \mathrm{~nm})$ and had a zeta potential of $(14.6$ and $16.4 \mathrm{mV})$. The increased potential in case of COS functionalized RGD could be attributed to the contribution of the positive charges from lysine and arginine amino acids on the peptide chain attached to the polymer. Thus, we selected the polymer/TPP ratio of $1: 1.5 \mathrm{w} / \mathrm{w}$ as the optimum one to be used for loading the anticancer agents ACIN and AMIN, Fig. 8. ACIN and AMIN showed a promising antiproliferative activity on a panel of cancer cell lines including SK-OV-3, MCF-7, and Hela [39]so we used them as drug templates. The drug-loaded nanoparticles exhibited relatively larger particle size and higher positive zeta potential values. The higher zeta potential was because the drug itself carry free amino group that contributes to the positive zeta potential of the NPs that carry the drug. The drug loading efficacy was calculated based on the amount of recovered from the drug after loading (Table 2).

\subsubsection{Cytotoxic efficacy of ACIN, AMIN loaded COS and COS-SMCC-GGRGDSK NPs.}

We investigated the ability of COS-SMCC-GGRGDSK in translocating ACIN and AMIN into the cancer cells and enhance their cytotoxic potency using the prostate cancer cell lines DU-145 and leukemia cancer cell lines CCRF-CEM as model cells in our study. Since ACIN and AMIN suffer from the limitation of solubility in aqueous solutions, we hypothesized that loading them onto water soluble drug delivery systems such as COS and COS-SMCC-GGRGDSK NPs can improve their solubility and enhance their cellular uptake, and their cytotoxicity profile in the cancer cells.

The free form and the loaded forms on either COS or COS-SMCC-GGRGDSK were assayed on both DU-145 and CCRF-CEM cell lines at $30 \mu \mathrm{M}$ for $96 \mathrm{~h}$. As shown in Fig. 9, ACIN alone was a potent cytotoxic agent in both DU-145 and CCRF-CEM cell lines. ACIN antiproliferative activity was quenched upon its loading onto COS NPs since the cell viability reached $60 \%$ in DU-145 and $50 \%$ in CCRF-CEM cell lines. Meanwhile, ACIN loaded COS-SMCC-GGRGDSK NPs are consistently slightly more potent in CCRF-CEM and DU-145 cell lines. AMIN-loaded COS-SMCCGGRGDSK NPs are consistently slightly more potent in CCRF-CEM cell line as compared to ACIN and PTX. Also, AMIN-loaded COS-SMCC-GGRGDSK NPs are slightly less potent in DU-145 cell line as compared to ACIN where as it is found to be more potent as compared to AMIN and PTX. For example, a similar pattern of cytotoxicity behavior was exhibited by AMIN, which showed moderate antiproliferative activities of $65 \%$ and $74 \%$ cell viability in DU-145 and CCRF-CEM cells, 
respectively. AMIN loaded COS NPs showed $85 \%$ cell viability in DU-145, but the antiproliferative activity was enhanced by $44 \%$ in CCRF-CEM cell lines. The cytotoxicity of AMIN was strongly enhanced by loading to COS-SMCC-GGRGDSK NPs, as the cell viability was diminished to $22 \%$ and $11 \%$ in both DU-145 and CCRF-CEM cells, respectively. It confirms the role of COS-SMCCGGRGDSK NPs in improving the antiproliferative activity profile of ACIN and AMIN compounds, indicating the synergistic effect of both chitosan backbone and the peptide motif in suppressing the growth of DU-145 and CCRF-CEM cancer cells.

\section{Conclusions}

We have successfully immobilized RGD containing peptide motif on the surface of chitosan via a (sulfo-SMCC) linker, with structure characterization. The new delivery system showed negligible cytotoxic profile. COS-GGRGDSK successfully translocated a number of biologically active cell impermeable cargoes. The results suggest that COS-modified GGRGDSK is a promising delivery system that can be used for the delivery of molecular probes, such as the cell impermeable phosphopeptide and FAM dye to the cancer cells. The cellular uptake study for the copolymer proved to be partially endocytosis and energy dependent. Ionic gelation method was used to formulate nanoparticles using different weight ratios of the copolymer to TPP. The improved cytotoxicity of ACIN and AMIN efficacy by their loading with COS-GGRGDSK NPs provide insights to investigate further their in vivo efficacy against the prostate and leukemia cancer models.

\section{Notes}

The authors declare that they do not have competing or conflicting interests.

\section{Acknowledgments}

The authors would like to thank the Egyptian Cultural Affairs and Mission Sector, Ministry of Higher Education, Egypt and Chapman University School of Pharmacy for the financial support. The University of California in Irvine for providing the facilities for running this research.

\section{References}

[1] D. Mandal, A.N. Shirazi, K. Parang, Cell-penetrating homochiral cyclic peptides as nuclear-targeting molecular transporters, Angew. Chem. Int. Ed. 50 (2011) 9633-963. 
[2] J. Lu, Z. Li, J.I. Zink, F.Tamanoi, In vivo tumor suppression efficacy of mesoporous silica nanoparticles-based drug-delivery system: enhanced efficacy by folate modification, Nanotechnol. Biol. Med. 8 (2012) 212-220.

[3] H.J. Cho, I.S. Yoon, H.Y. Yoon, H. Koo, Y.J. Jin, S.H. Ko, J.S. Shim, K. Kim, I.C. Kwon, D.D. Kim, Polyethylene glycol-conjugated hyaluronic acid-ceramide self-assembled nanoparticles for targeted delivery of doxorubicin, Biomaterials 33 (2012) 1190-1200.

[4] M.A. Casadei, F. Cerreto, S. Cesa, M. Giannuzzo, M. Feeney, C. Marianecci, P. Paolicelli, Solid lipid nanoparticles incorporated in dextran hydrogels: a new drug delivery system for oral formulations, Int. J. Pharm. 325 (2006) 140-146.

[5] X. Nie, J. Zhang, Q. Xu, X. Liu, Y. Li, Y. Wu, C. Chen, Targeting peptide iRGDconjugated amphiphilic chitosan-co-PLA/DPPE drug delivery system for enhanced tumor therapy, J. Mater. Chem. B. 2 (2014) 3232-3242.

[6] R. Riva, H. Ragelle, A. des Rieux, N. Duhem, C. Jerome, V. Preat, Chitosan and Chitosan Derivatives in Drug Delivery and Tissue Engineering, Adv. Polym. Sci. 244 (2011) 19-44.

[7] A.B. Schnürch, S. Dünnhaupt, Chitosan-based drug delivery systems, Eur. J. Pharma. Biopharm. 81 (2012) 463-469.

[8] N.G. Schipper, S. Olsson, J.A. Hoogstraate, A.G. Boer, K.M. Varum, P. Artursson, Chitosans as absorption enhancers for poorly absorbable drugs 2: mechanism of absorption enhancement, Pharm. Res. 14 (1997) 923-929.

[9] C.E. Thomas, A. Ehrhardt, M.A. Kay, Progress and problems with the use of viral vectors for gene therapy, Nat. Rev. Genet. 4 (2003) 346-358.

[10] S.H. Kim, J.H. Jeong, K.C. Chul, S. Wan Kim, T.G. Park. Target-specific gene silencing by siRNA plasmid DNA complexed with folate-modified poly(ethylenimine), J. Control. Release 104 (2005) 223-232.

[11] B. Liang, M.L. He, C. Chan, Y.C. Chen, X.P. Li, Y. Li, D. Zheng, M. Lin, H.F. Kung, X.T. Shuai, Y. Peng, The use of folate-PEG-grafted-hybranched-PEI nonviral vector for the inhibition of glioma growth in the rat, Biomaterials 30 (2009) 4014-4020. 
[12] T.S.C. Lia, T. Yawata, K. Honke, Efficient siRNA delivery and tumor accumulation mediated by ionically cross-linked folic acid-poly(ethylene glycol)-chitosan oligosaccharide lactate nanoparticles: for the potential targeted ovarian cancer gene therapy, Eur. J. Pharm Sci. 52 (2014) 48-61.

[13] X. Zhao, Z. Li, W. Liu, W. Lam, P. Sun, R.Y.T. K. Keith, D.K. Luk, W.W. Lu, Octaarginine-modified chitosan as a nonviral gene delivery vector: properties and in vitro transfection efficiency, J. Nanopart. Res. 13 (2011) 693-702.

[14] U. Termsarasab, H.J. Cho, D.H. Kim, S. Chong, S.J. Chung, C.K. Shim, H.T. Moon, D.D. Kim, Chitosan oligosaccharide-arachidic acid-based nanoparticles for anti-cancer drug delivery, Int. J. Pharm. 441 (2013) 373-380.

[15] M. Li, W. Song, Z. Tang, S. Lv, L. Lin, H. Sun, Q. Li, Y. Yang, H. Hong, X. Chen, Nanoscaled poly(L-glutamic acid)/doxorubicin-amphiphile complex as pH-responsive drug delivery system for effective treatment of nonsmall cell lung cancer, ACS Appl. Mater. Interfaces 5 (2013) 1781-1792.

[16] W.A. Denny, Hypoxia-activated prodrugs in cancer therapy: progress to the clinic, Future Oncol. 6 (2010) 419-428.

[17] Angelo Corti, Fabio Pastorino, Flavio Curnis, Wadih Arap, Mirco Ponzoni and, Renata Pasqualin, Targeted Drug Delivery and Penetration Into Solid Tumors, Med. Res. Rev. 32, (2012) 1078-1091.

[18] J.H. Park, G. Saravanakumar, K. Kim, Targeted delivery of low molecular drugs using chitosan and its derivatives, Adv. Drug Deliv. Rev. 62 (2010) 28-41.

[19] H. Wang, P. Zhao, X. Liang, X. Gong, T. Song, R. Niu, J. Chang, Folate-PEG coated cationic modified chitosan-cholesterol liposomes for tumor-targeted drug delivery, Biomaterials 31 (2010) 4129-4138.

[20] D. Zheng, C. Duan, D. Zhang, L. Jia, G. Liu, Y. Liu, F. Wang, C. Li, H. Guo, Q. Zhang, Galactosylated chitosan nanoparticles for hepatocyte-targeted delivery of oridonin, Int J. Pharm. 436 (2012) 379-86. 
[21] M.K. Yoo, S. K. Kang, J. H. Choi, I. K. Park, H. S. Na, H. C. Lee, E. B. Kim, N. K. Lee, J. W. Nah, Y. J. Choi, C. S. Cho, Targeted delivery of chitosan nanoparticles to Peyer's patch using M cell-homing peptide selected by phage display technique, Biomaterials 31 (2010) $7738-7747$.

[22] J.P. Nam, S.C. Park, T.H. Kim, J.Y. Jang, C. Choi, M.K. Jang, J.W. Nah, Encapsulation of paclitaxel into lauric acid-O-carboxymethyl chitosan-transferrin micelles for hydrophobic drug delivery and site-specific targeted delivery, Int. J. Pharm. 457 (2013) 124-135

[23] Y. Gao, Z. Y. Wang, J. Zhang, Y. Zhang, H. Huo, T. Wang, T. Jiang, S. Wang, RVGpeptide-linked trimethylated chitosan for delivery of siRNA to the brain, Biomacromol. 15 (2014) 1010-1018.

[24] J.S. Desgrosellier, D.A. Cheresh, Integrins in cancer: biological implications and therapeutic opportunities, Nat. Rev. Cancer 10 (2010) 9-22.

[25] F. Danhier, O. Feron, V. Préat, To exploit the tumor microenvironment: Passive and active tumor targeting of nanocarriers for anti-cancer drug delivery, J. Control. Release 148 (2010) 135-146.

[26] H.D. Han, L.S. Mangala, J.W. Lee, M.M. Shahzad, H.S. Kim, D. Shen, E.J. Nam, E. M. Mora, R.L. Stone, C. Lu, S.J. Lee, J.W. Roh, A.M. Nick, G.L. Berestein, A.K. Sood, Targeted gene silencing using RGD-labeled chitosan nanoparticles, Clin. Cancer Res. 16 (2010) 3910-3922.

[27] F. Danhier, A.L. Breton, V. Preat, RGD-based strategies to target alpha(v) beta(3) integrin in cancer therapy and diagnosis, Mol. Pharm. 9 (2012) 2961-2973.

[28] A. Hansson, N. Hashom, F. Falson, P. Rousselle, O. Jordan, G. Borchard, In vitro evaluation of an RGD-functionalized chitosan derivative for enhanced cell Adhesion, Carbohydr. Polym. 90 (2012) 1494- 1500.

[29] T. Masuko, N. Iwasaki, S. Yamane, T. Funakoshi, T. Majima, A. Minami, N. Ohsuga, T. Ohta, S.I. Nishimura, Chitosan-RGDSGGC conjugate as a scaffold material for musculoskeletal tissue engineering, Biomaterials 26 (2005) 5339-5347. 
[30] T.T. Kazuki, N. Sugahara, V.R. Kotamraju, E. Ruoslahti, C-end rule peptides mediate neuropilin-1-dependent cell, vascular, and tissue penetration, PNAS 22 (2009) 1615716162.

[31] Y. Wu, W. Yang, C. Wang, J. Hu, S. Fu, Chitosan nanoparticles as a novel delivery system for ammonium glycyrrhizinate, Int. J. Pharm. 295 (2005) 235-245.

[32] G. Crini, G. Torri, M. Guerrini, M.M. Weltrowskic, B. Martel, NMR characterization of Nbenzyl sulfonated derivatives of chitosan, Carbohydr. Polym. 33 (1997) 145-151.

[33] M. Rinaudo, Chitin and chitosan: Properties and applications, Prog. Polym. Sci. 31 (2006) 603-632.

[34] C.Y. Yan, J.W. Gu, D.P Hou, H.Y. Jing, J. Wang, Y.Z. Guo, H. Katsumi, T. Sakane, A. Yamamoto, Synthesis of Tat tagged and folate modified N-succinyl-chitosan self-assembly nanoparticles as a novel gene vector, Int. J. Biol. Macromol. 72 (2015) 751-756.

[35] I. Mellman, Endocytosis and molecular sorting, Annu. Rev. Cell Dev. Biol. 12 (1996) 575625 .

[36] R.B. Jones, A. Gordus, J.A. Krall, G. MacBeath, A quantitative protein interaction network for the ErbB receptors using protein microarrays, Nature 439 (2006) 168-174.

[37] L.H. Wang, K.G. Rothberg, R.G. Anderson, Mis-assembly of clathrin lattices on endosomes reveals a regulatory switch for coated pit formation, J. Cell Biol. 123 (1993) $1107-1117$.

[38] G.J. Doherty, H.T. McMahon, Mechanisms of endocytosis, Annu. Rev. Biochem. 78 (2009) 13-23.

[39] A.N. Shirazi, R.K. Tiwari, D. Oh, A. Banerjee, A. Yadav, K. Parang, Efficient Delivery of Cell Impermeable Phosphopeptides by a Cyclic Peptide Amphiphile Containing Tryptophan and Arginine, Mol. Pharmaceutics 10 (2013) 2008-2020.

[40] N.S. El-Sayed, A.N. Shirazi, M.G. El-Meligy, A.K. El-Ziaty, D. Rowley, J. Sun, Z.A. Nagib, K. Parang, Synthesis of 4-aryl-6-indolylpyridine-3-carbonitriles and evaluation of their antiproliferative activity, Tetrahedron Lett. 55 (2014) 1154-1158. 


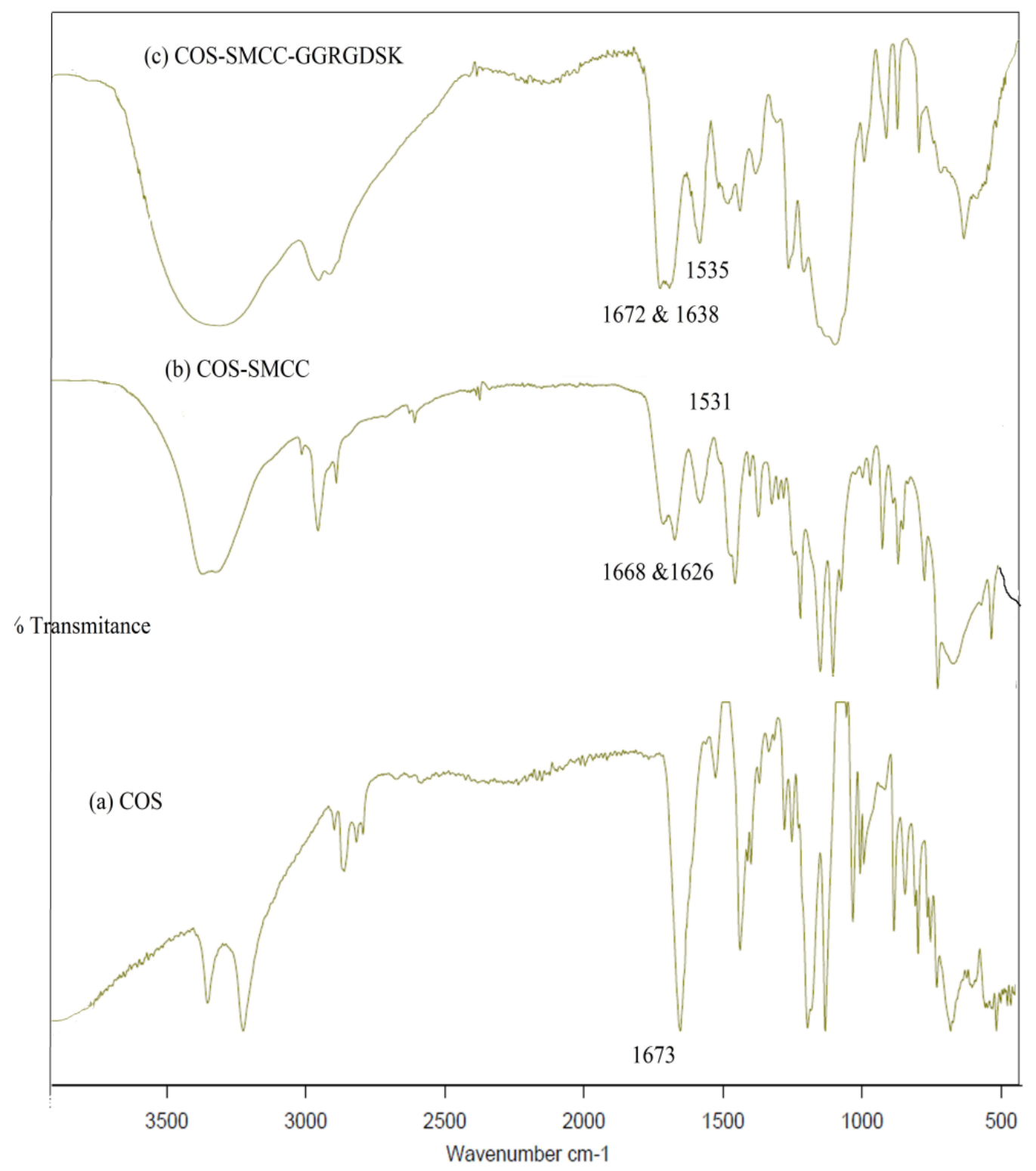

Fig. 1. FT-IR for COS (a), COS-SMCC (b), and COS-SMCC-GGRGDSK (c). 

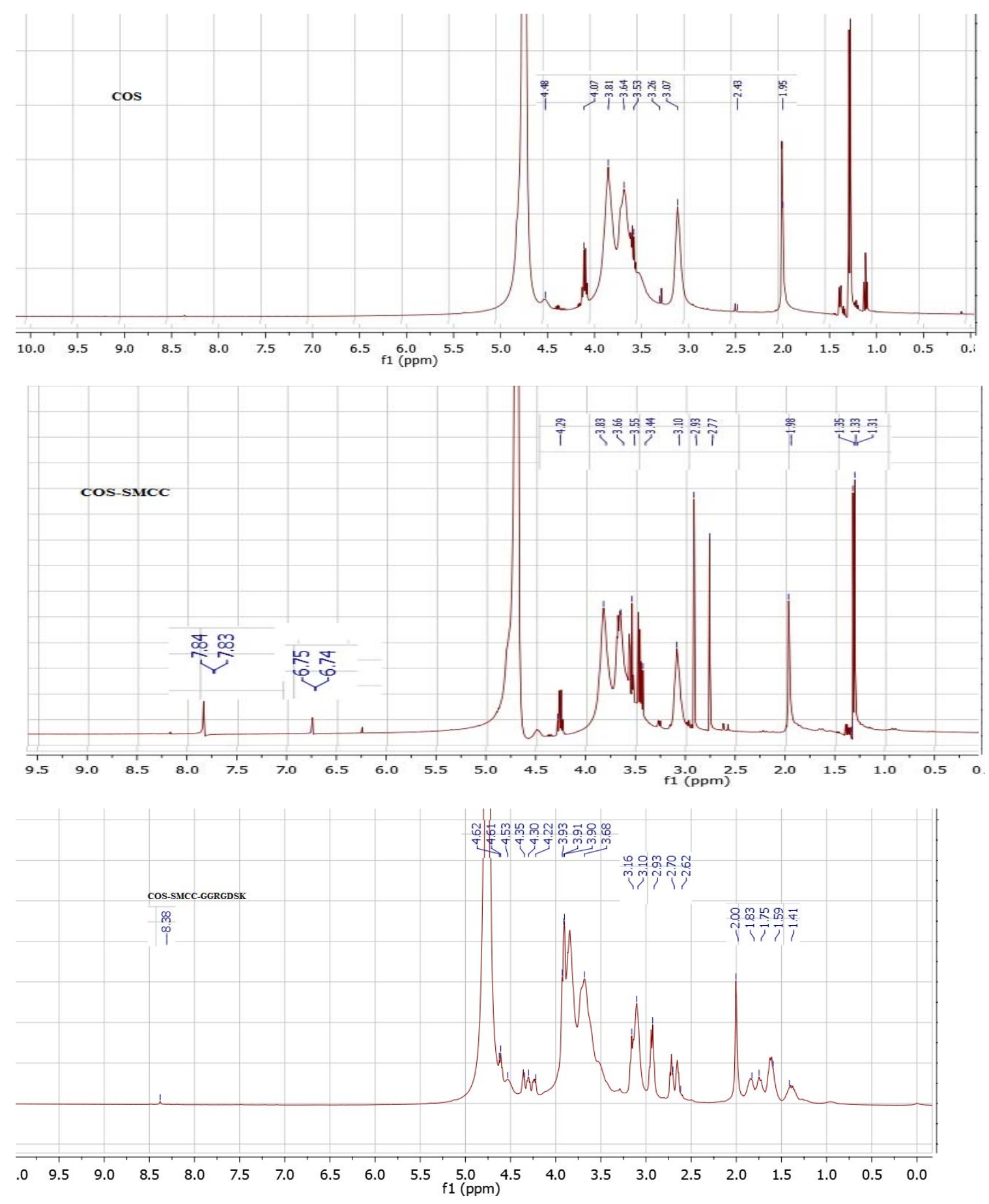

Fig. 2a. ${ }^{1} \mathrm{H}-\mathrm{NMR}$ spectra of COS, COS-SMCC, and COS-SMCC-GGRGDSK in $\mathrm{D}_{2} \mathrm{O}$. 

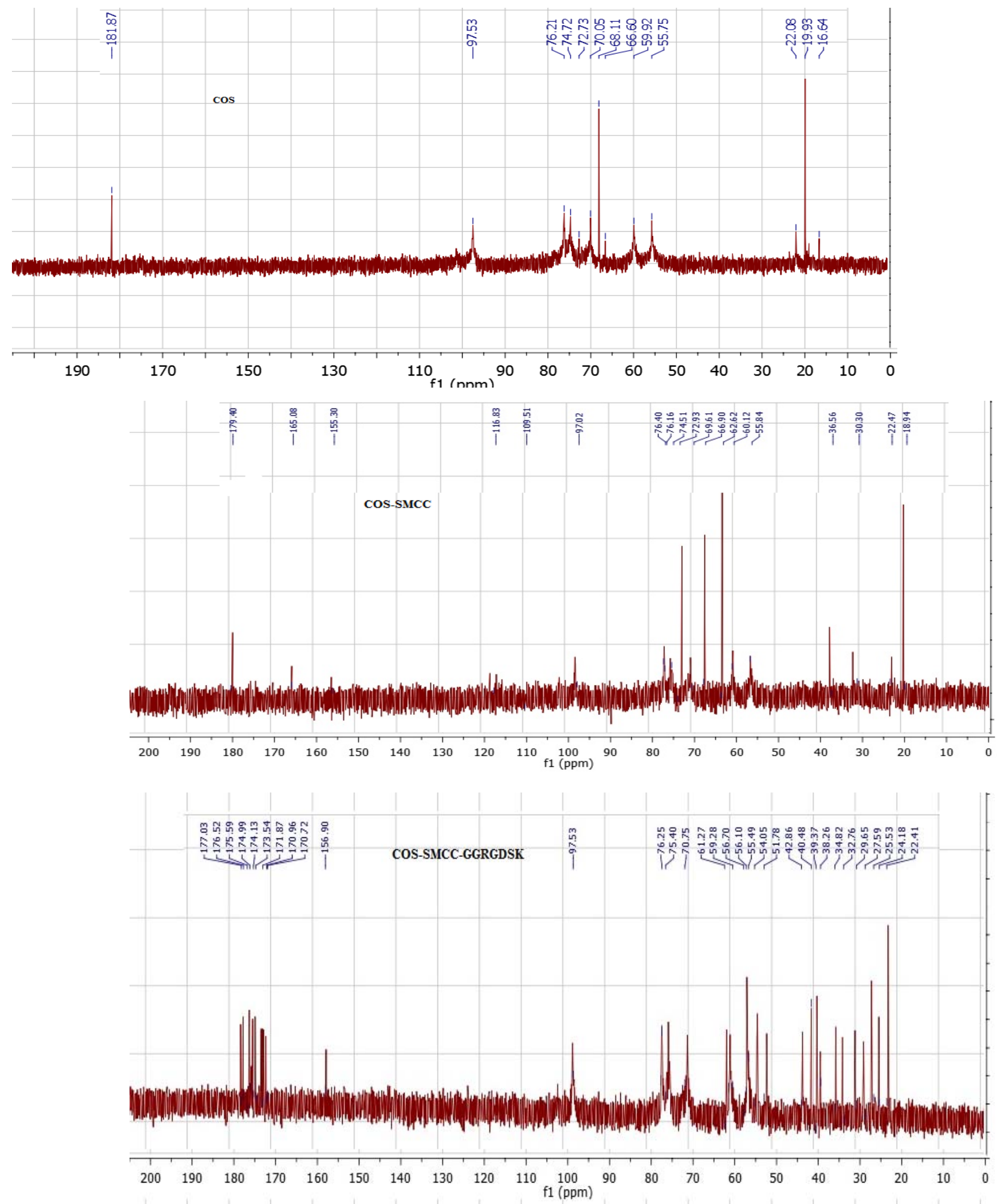

Fig. 2b. ${ }^{13} \mathrm{C}-\mathrm{NMR}$ spectra of COS, COS-SMCC, and COS-SMCC-GGRGDSK in $\mathrm{D}_{2} \mathrm{O}$. 

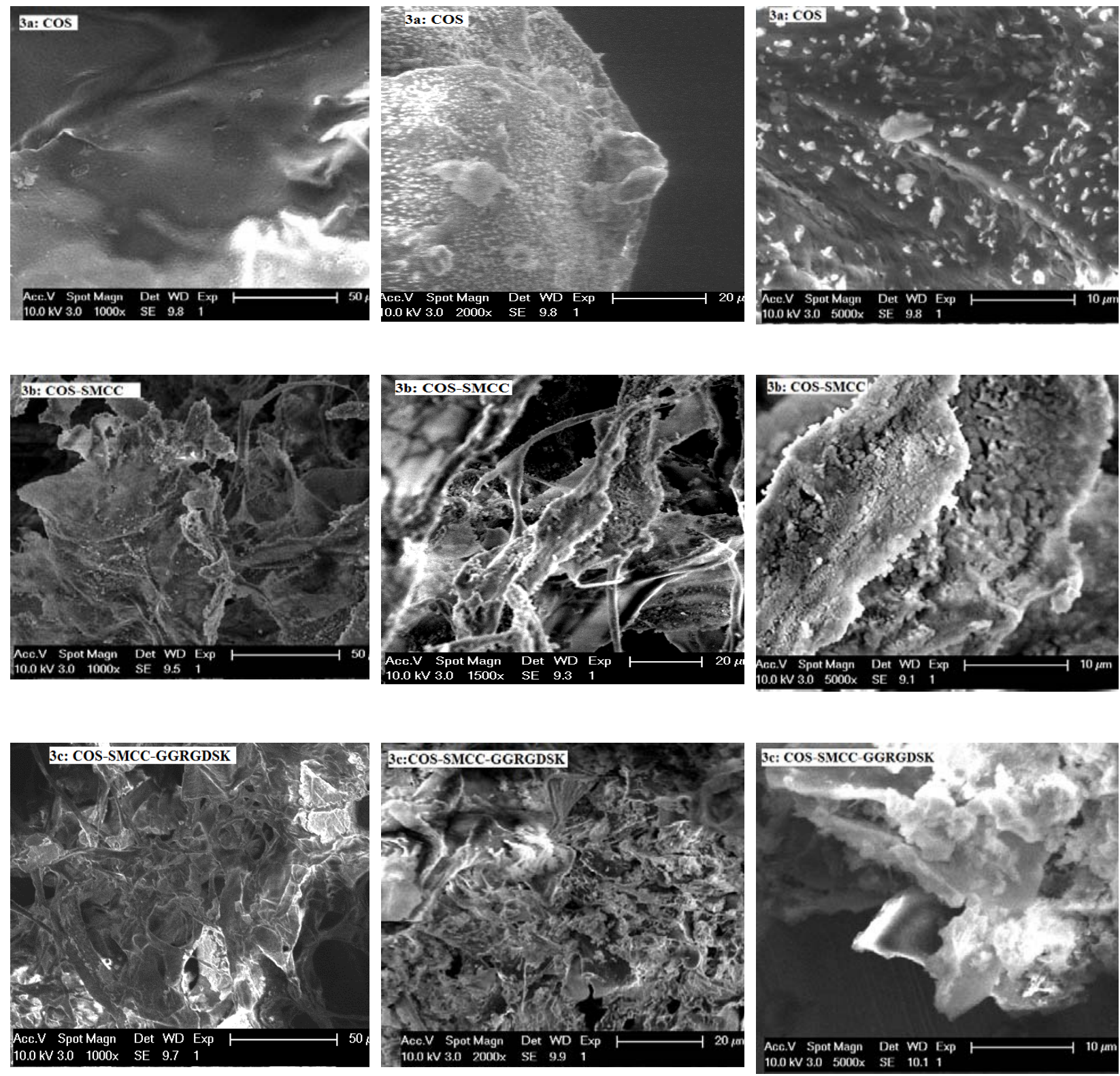

Fig. 3. Scanning electron micrographs of COS (a), COS-SMCC linker (b), and COS -SMCCGGRGDSK (c). 


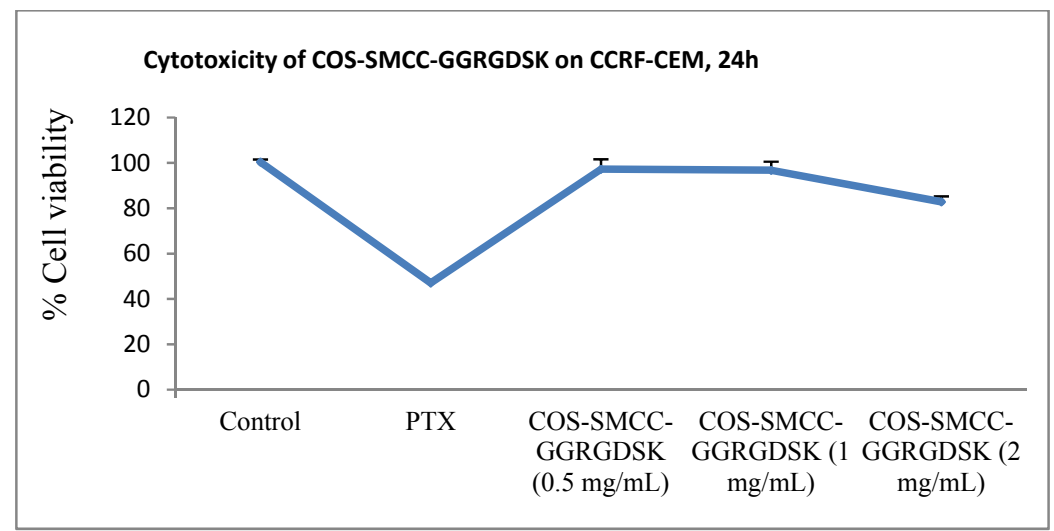

Fig. 4. Cytotoxicity assay of the COS-SMCC-GGRGDSK at $1 \mathrm{mg} / \mathrm{mL}$ after $3 \mathrm{~h}$ incubation with CCRF-CEM, and SK-OV-3 cells.

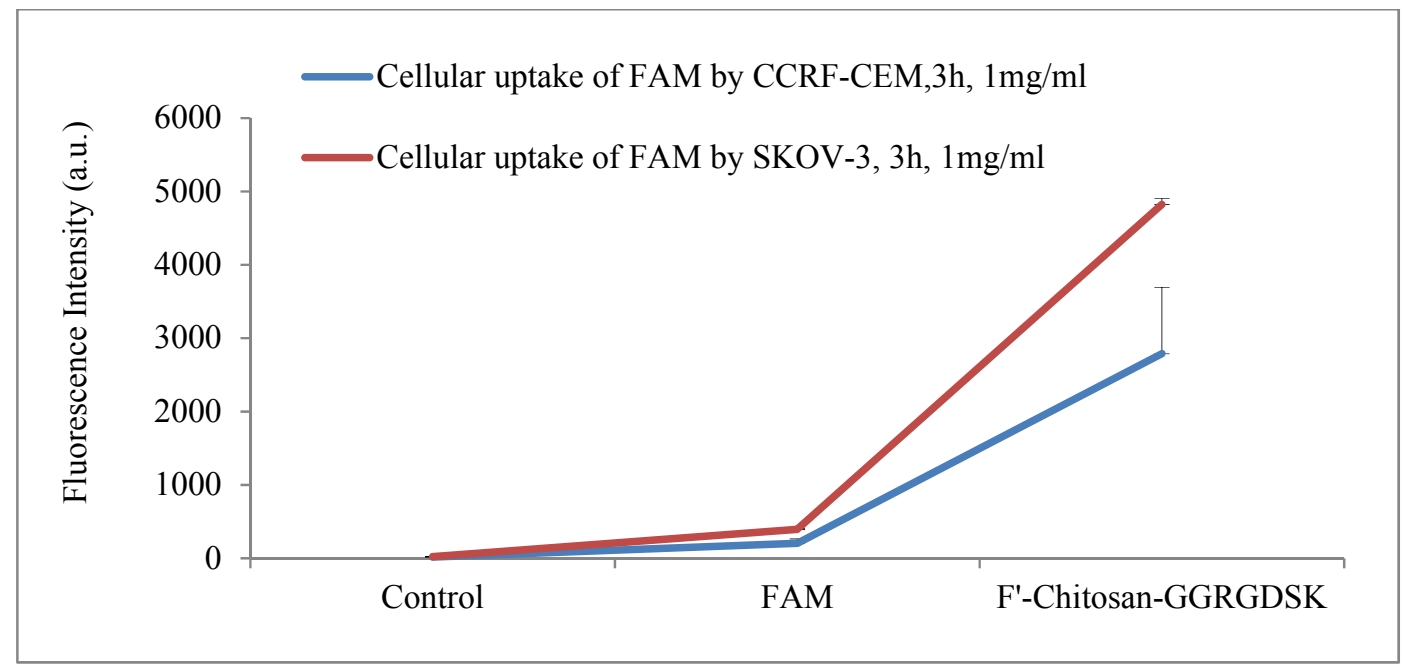

Fig. 5. Cellular uptake of COS-SMCC-GGRGDSK(F'), and free FAM $(0.5,1$, and $2 \mathrm{mg} / \mathrm{ml})$ in CCRF-CEM cells after $24 \mathrm{~h}$. 


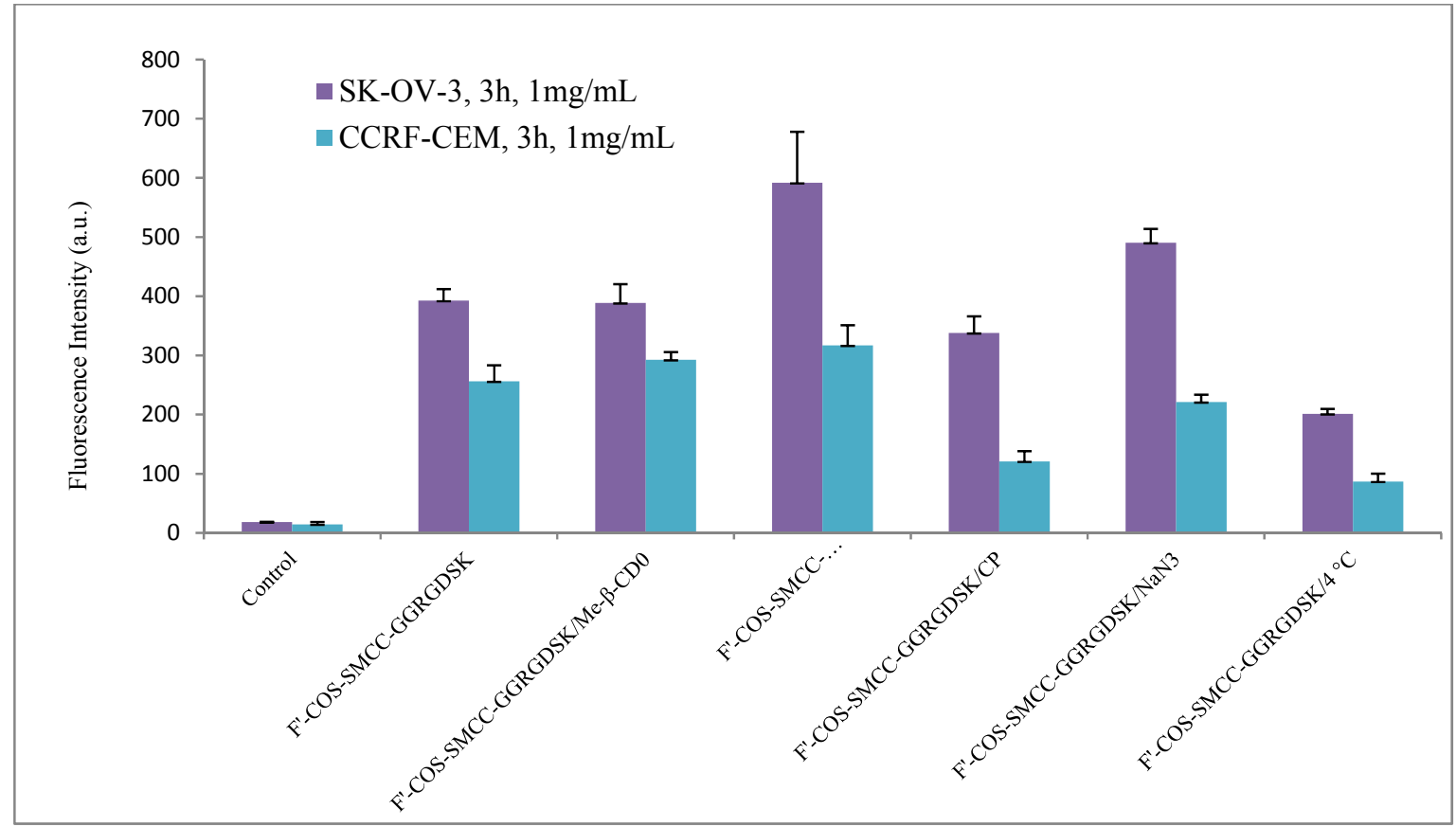

Fig. 6. Mechanistic study of for COS-GGRGDSK $\left(F^{\prime}\right)$ at $(5 \mu \mathrm{M})$ in the presence of endocytic inhibitors and sodium azide in CCRF-CEM cells and SK-OV-3.

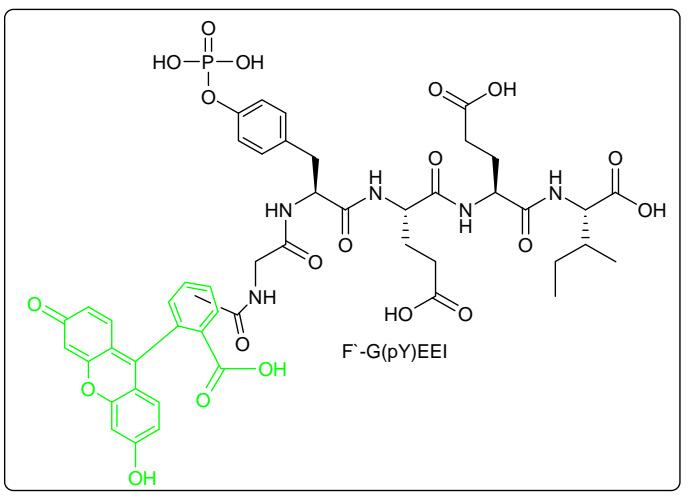

Fig. 7a. The structure of phosphopeptide F'-GPYEEI. 


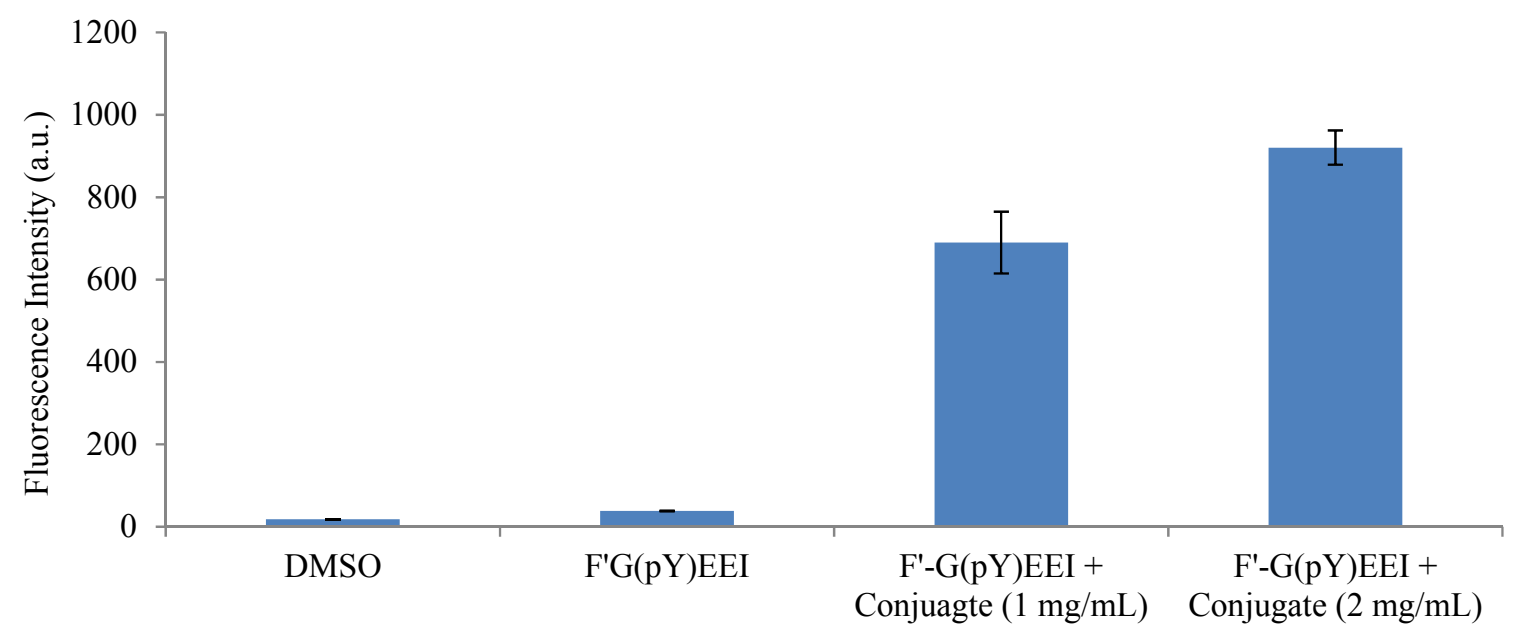

Fig. 7b. Cellular uptake of fluorescently-labeled peptide F`-GPYEEI $(5 \mu \mathrm{M})$ after $3 \mathrm{~h}$ incubation with CCRF-CEM cells.<smiles>N#Cc1c(Br)cc(-c2c[nH]c3ccccc23)nc1NCCN</smiles>

Fig. 8. The chemical structure of ACIN and AMIN.

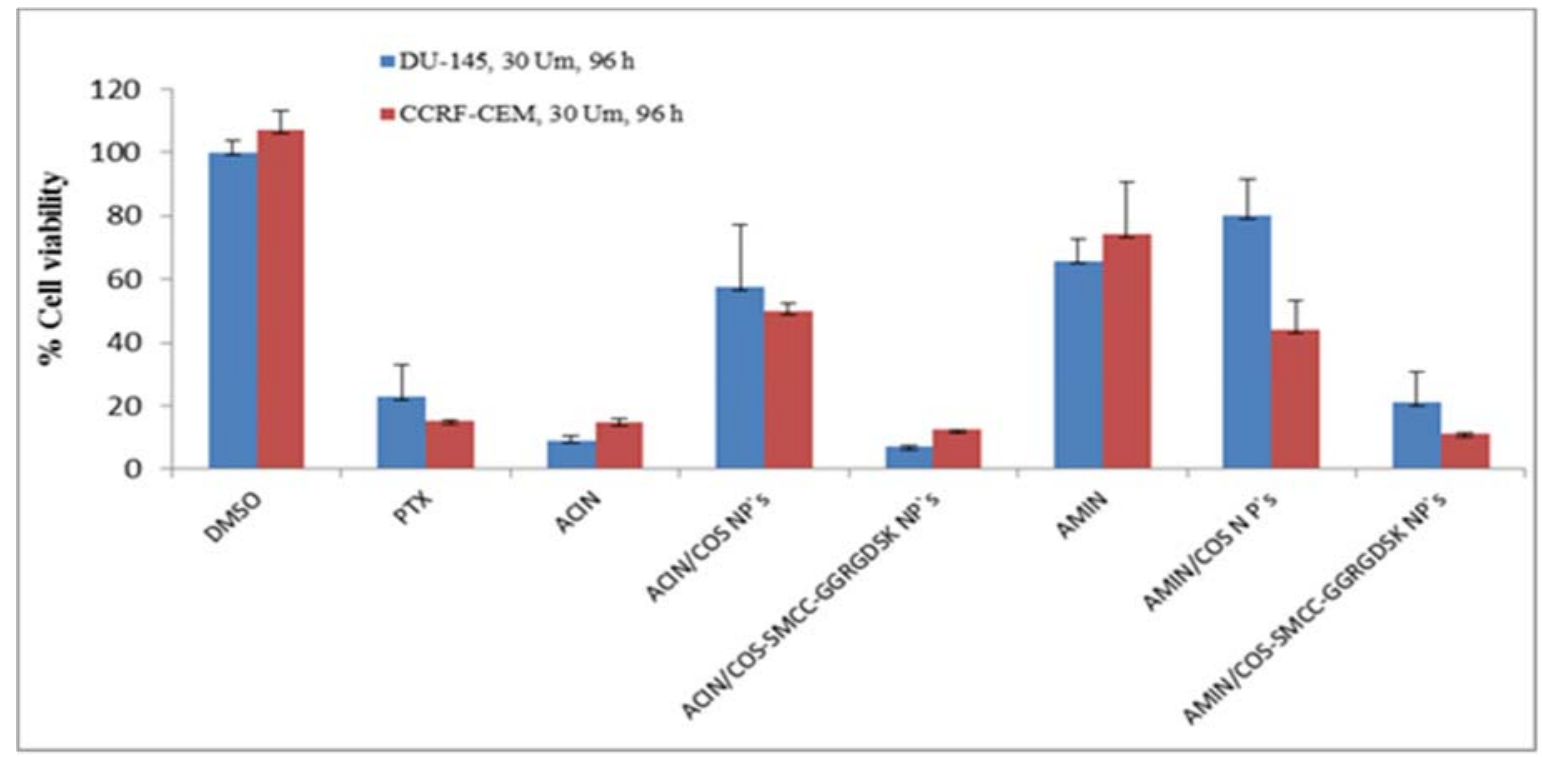

Fig. 9. Antiproliferative activity of ACIN, AMIN in three different formulations. 

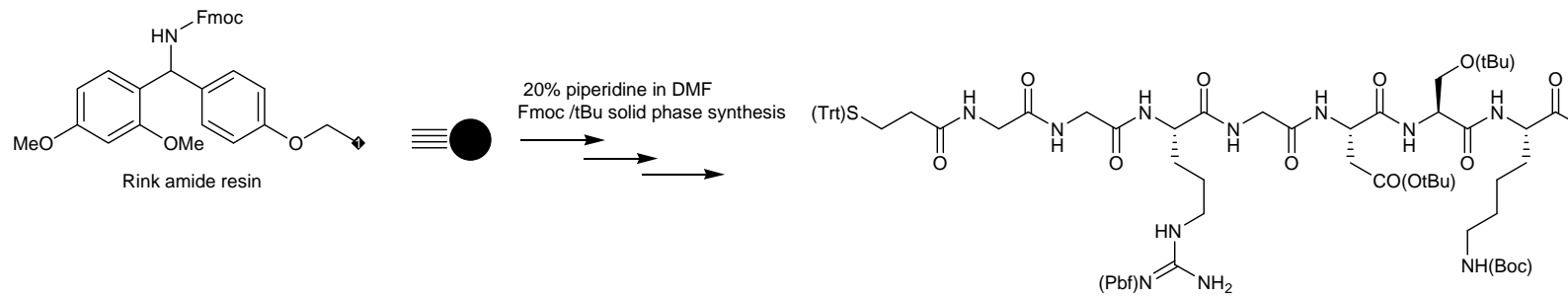

Cleavage using reagent $\mathrm{R}$ (TFA/Thioanisole/Anisole/Ethanedithiol) 90:5:2:3 v/v/v/v, $6 \mathrm{~h}$ )

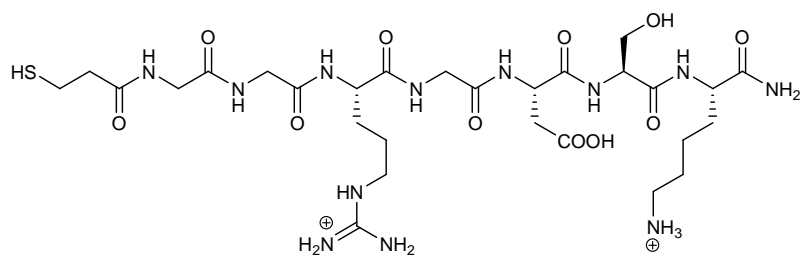

HS- $\left(\mathrm{CH}_{2}\right)_{2} \mathrm{CONH-GGRGDSK-CONH}{ }_{2}$

Scheme 1. Synthesis of HS- $\left(\mathrm{CH}_{2}\right)_{2} \mathrm{CONH}-\mathrm{GGRGDSK}-\mathrm{CONH}_{2}$.<smiles>N=C(N)NCCC[C@H](NC(=O)CNC(=O)CNC(=O)CCS)C(=O)NCC(=O)N[C@@H](CC(=O)O)C(=O)NC(CO)C(=O)N[C@@H](CCCCCN)C(N)=O</smiles>

1.5 equiv of $5(6)$ carboxyfluorescein- $N$ hydroxysuccinimide ester, 6 equiv. DIPEA $1 \mathrm{ml} \mathrm{DMF} / \mathrm{N}_{2} / 24 \mathrm{~h}$ HS- $\left(\mathrm{CH}_{2}\right)_{2} \mathrm{CONH-GGRGDSK-CONH}{ }_{2}$ hydroxysuccinimide ester

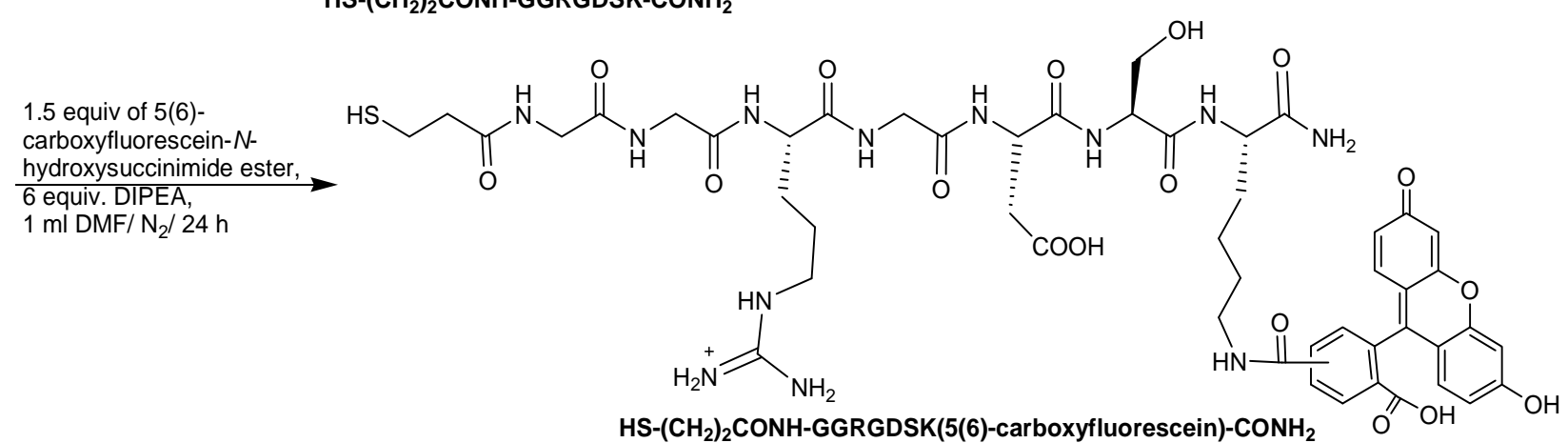

Scheme 2. Synthesis of COS-SMCC-GGRGDSK(F'). 


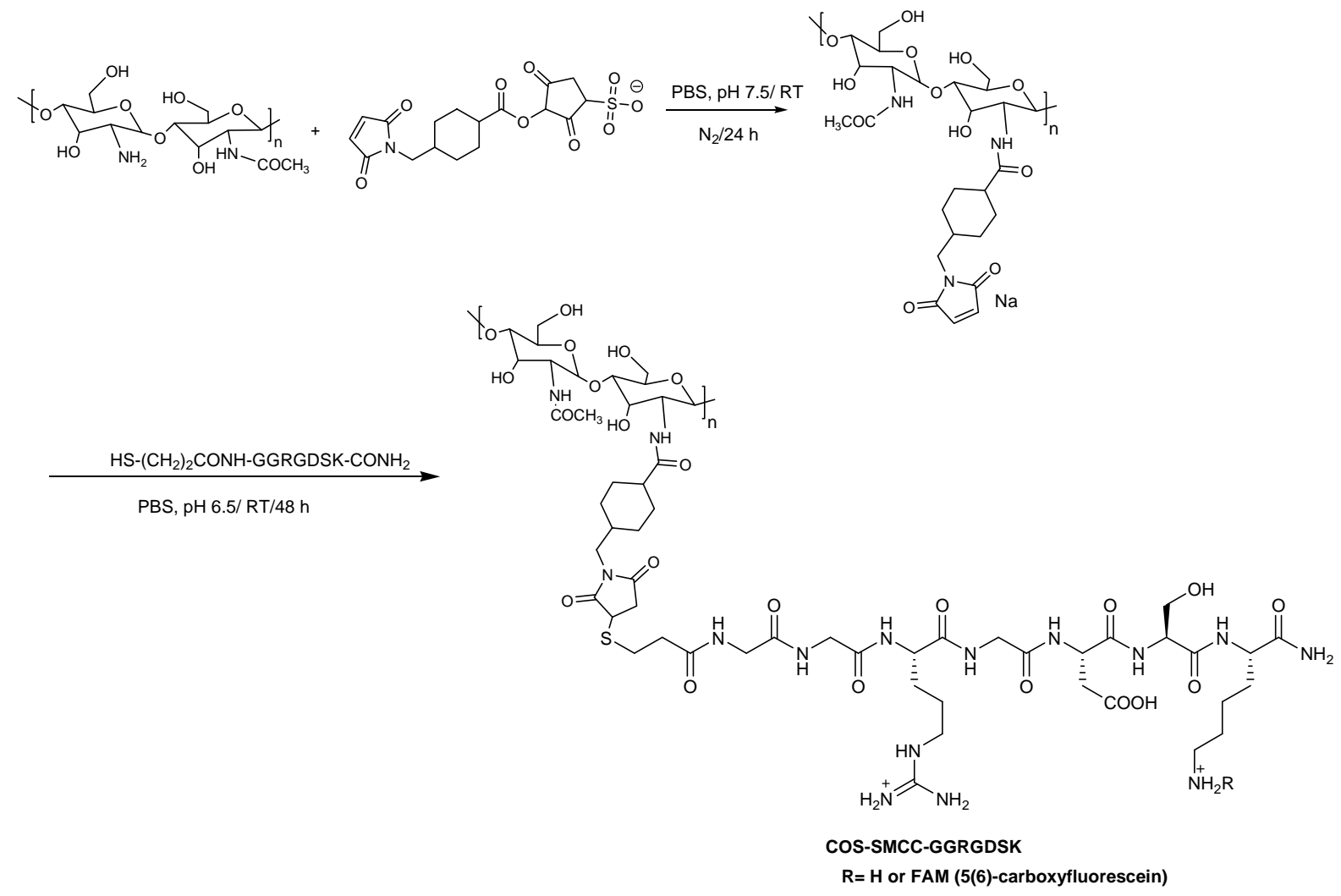

Scheme 3. Coupling of the peptide or the fluorescence-labeled peptide to COS-SMCC. 
Table 1. The size, PDI, and zeta potential of the COS and COS-RGD NPs at different ratios of TPP.

\begin{tabular}{|l|l|l|l|l|l|l|l|l|l|}
\hline & $\begin{array}{l}\text { Polymer/TPP } \\
\text { Wt/Wt }\end{array}$ & $\begin{array}{l}\text { Zeta } \\
\text { size } \\
\mathbf{( n m}\end{array}$ & PDI & $\begin{array}{l}\text { Zeta } \\
\text { potential } \\
\mathbf{( m V}\end{array}$ & Polymer & $\begin{array}{l}\text { Polymer/TPP } \\
\mathbf{W t} / \mathbf{W t}\end{array}$ & $\begin{array}{l}\text { Zeta } \\
\text { size } \\
\mathbf{( n m})\end{array}$ & $\begin{array}{l}\text { PDI } \\
\text { zeta } \\
\text { potential } \\
\mathbf{( m V})\end{array}$ \\
\hline COS /TPP & $1: 1$ & 285.1 & 0.270 & 17.55 & COS-RGD & $1: 1$ & 338.6 & 0.310 & 18.30 \\
\hline COS/TPP & $1: 1.5$ & 209.1 & 0.179 & 14.6 & COS-RGD & $1: 1.5$ & 301.7 & 0.280 & 16.4 \\
\hline COS/TPP & $1: 2$ & 187.3 & 0.164 & 12.2 & COS-RGD & $1: 2$ & 250.7 & 0.253 & 15.9 \\
\hline
\end{tabular}

Table 2. The size, PDI, and zeta potential of the COS, and COS-RGD NPs loaded with ACIN \& AMIN polymer/ TPP ratio 1:1.5.

\begin{tabular}{|l|l|l|l|l|}
\hline Polymer & Zeta size (nm) & PDI & zeta potential (mV) & Loading efficacy \% \\
\hline ACIN/COS & 186.6 & 0.203 & 13.52 & 25.2 \\
\hline AMIN/COS & 257.9 & 0.410 & 15.59 & 23.2 \\
\hline ACIN/COS-GGRGDSK & 225.2 & 0.364 & 17.5 & 28.9 \\
\hline AMIN/COS-GGRGDSK & 246.5 & 0.212 & 17.9 & 27.2 \\
\hline
\end{tabular}

